Article

\title{
Potential of Windbreak Trees to Reduce Carbon Emissions by Agricultural Operations in the US
}

\author{
William Ballesteros-Possu ${ }^{1, *}$, James R. Brandle ${ }^{2}$ and Michele Schoeneberger ${ }^{3}$ \\ 1 Faculty of Agricultural Sciences, Universidad de Nariño, San Juan de Pasto, Nariño 520002, Colombia \\ 2 School of Natural Resources, University of Nebraska, 3310 Holdrege Street, Lincoln, NE 68583-0995, USA; \\ jbrandle1@unl.edu \\ 3 United States Department of Agriculture, Forest Service, National Agroforestry Center, East Campus-UNL, \\ Lincoln, NE 68583-0822, USA; mschoeneberger@fs.fed.us \\ * Correspondence: wballesterosp@gmail.com; Tel.: +57-3-154019339; Fax: +57-2-7313315
}

Academic Editors: P. K. Ramachandran Nair and Timothy A. Martin

Received: 1 March 2017; Accepted: 18 April 2017; Published: 26 April 2017

\begin{abstract}
Along with sequestering $C$ in forest, trees on farms are able to contribute to greenhouse mitigation through emission avoidance mechanisms. To evaluate the magnitude of these contributions, emission avoidance contributions for field and farmstead windbreak designs in regions across the United States were estimated, along with greenhouse gas (GHG) emission budgets for corn, soybean, winter wheat, and potato operations. We looked at farming scenarios with large (600 ha), mid (300 ha), and small-size (60 ha) farms containing farmsteads built before and after 2000, and growing different cropping systems. Windbreak scenarios were assumed to be up to $5 \%$ of the crop area for field windbreaks, while emission avoidance for farmstead windbreaks were assumed to provide a $10 \%$ and $25 \%$ reduction in energy usage for space conditioning and heating, respectively. Total reduction of $C$ equivalent (CE) emissions by windbreaks on farm systems ranged from a low of $0.9 \mathrm{Mg} C E$ year $^{-1}$ for a 60-ha farm with a home built before 2000 to $39.1 \mathrm{Mg} \mathrm{CE}_{\text {year }}{ }^{-1}$ for a 600-ha farm with a home built after 2000. By reducing fossil fuel usage from farm operations, windbreaks provide a promising strategy for reducing GHG emissions from agriculture in the USA.
\end{abstract}

Keywords: agroforestry; carbon storage; greenhouse gas emissions; farmstead windbreak trees; avoided emissions (or energy savings)

\section{Introduction}

Carbon (C) storage and emission reduction approaches are being examined as greenhouse gas (GHG) mitigation strategies [1]. One such approach is a change in consumptive behavior resulting in reduction in fossil fuel usage, also referred to as avoided GHG emissions. In the agricultural sector, forestry and agroforestry are recognized as a suite of management practices that, besides providing several climate change adaptation services, can also provide both $\mathrm{C}$ sequestration and avoided GHG emission opportunities [2]. Within the suite of practices, incorporating field and farmstead windbreak practices into farm management plans seems to be a particularly promising option for storing carbon and for reducing emissions from farm operations [3]. 
Planting field windbreaks on agricultural lands reduces the cropping area, but generally more than compensates for this loss by increasing crop yields [4-11]. This reduction in land being farmed leads to a reduction in fuel use and other inputs (avoided emissions) as well as to other indirect benefits [3]. Avoided emissions via windbreaks on farms can also be achieved through the use of living snow fences, which reduces the need to clear snow from roads following snow events, which reduces fuel usage $[12,13]$, and through the use of farmstead windbreaks, which reduces energy needs for home heating and cooling [14-17]. Readers are referred to [18] for more information on windbreaks and these services. Information on the indirect impacts of agroforestry practices on the $C$ budget of a farm is limited compared to $C$ sequestration in the woody biomass of windbreak trees [19]. Rudimentary calculations by [3] suggest that the contribution of avoided emissions to the $\mathrm{C}$ budget may be even greater than sequestration contributions. Many believe trees belong only to forests; however, trees on farms such as in windbreaks, riparian zones, and orchards or woodlots make significant contributions to the $C$ budget by storing $C$ and avoiding fossil fuels emissions from farms operations. Here we consider the potential value of these agricultural 'trees outside of forests', specifically trees in windbreaks within farm operations, as a GHG mitigation strategy. The main objective of this study was to assess the indirect $C$ effects of field and farmstead windbreaks and the magnitude of these values within a farm's $C$ budget.

\section{Materials and Methods}

The basic input needs of a typical farm operation were developed based on published crop budgets for corn, soybean, potato, and winter wheat operations in Nebraska, Tennessee, Ohio, Montana, Texas, Iowa, Wisconsin, Idaho, Colorado, and Kansas as representative states of the nine regions we defined (Figure 1). Data from these locations and cropping systems were used to estimate $C$ equivalent (CE) emissions for the various farm operations. Because energy use for irrigation was considerable, crops were grouped as either irrigated or as non-irrigated cropping operations. It was assumed that 5 percent of the crop area was removed from production and occupied by field windbreaks. Five percent was selected as it is the threshold for the economic advantage of field windbreaks. If more than $5 \%$ of the land is planted to windbreaks it is very difficult to justify field windbreaks from a purely economic position. In other words, giving up $5 \%$ or less of the land to windbreaks pays; whereas above $5 \%$ we start losing profit from grain production [20]. From these areas, the reduction of fuel, fertilizer, and pesticide use was calculated. Data from the Residential Energy Consumption Survey (RECS) of the U.S. Energy Information Administration [21] were used to estimate farmstead size and use of electricity, natural gas, propane, and other fuels in different climatic zones (Figure 1). 


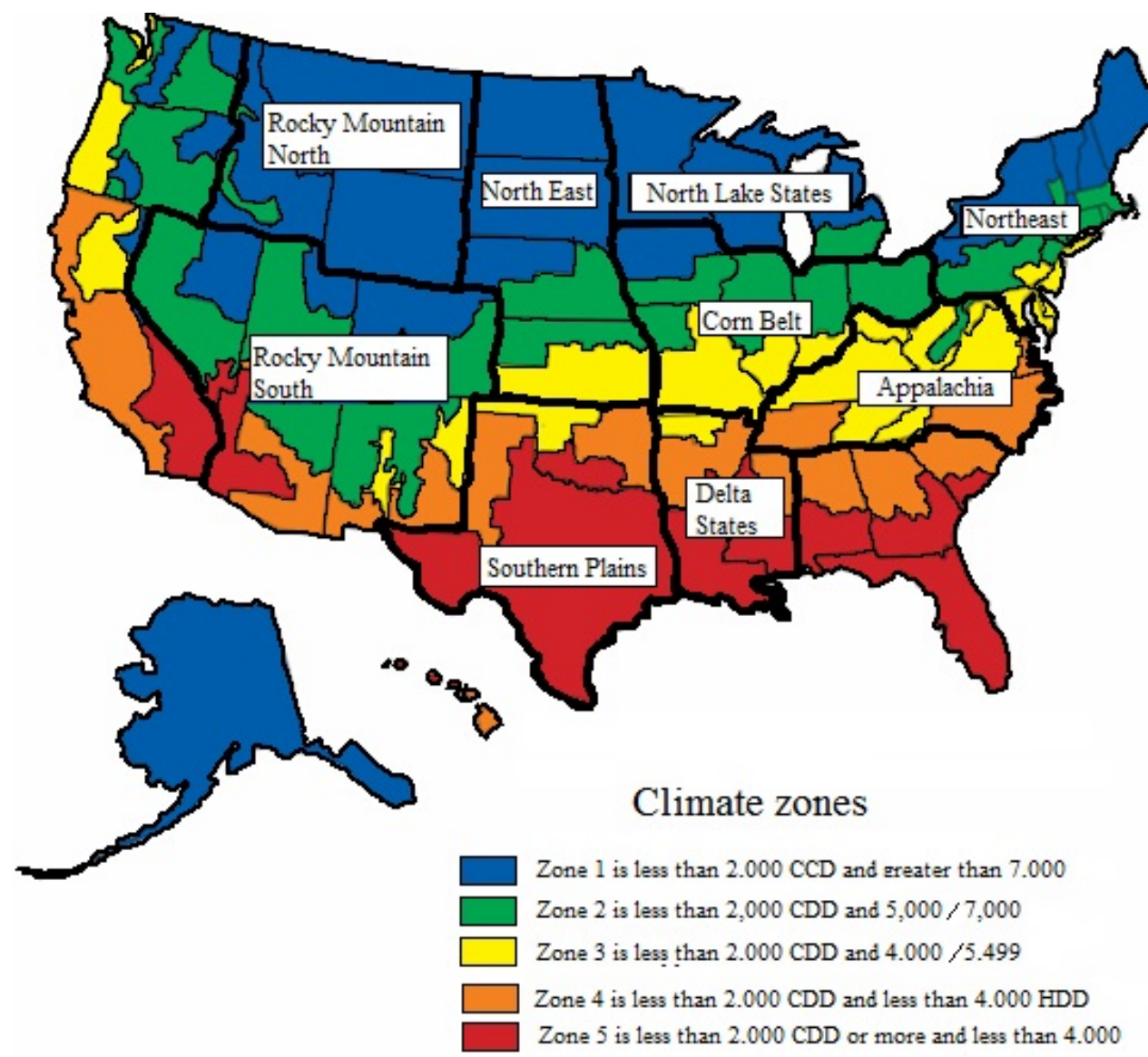

Figure 1. Climate zones in the continental United States. CCD = Cooling Degree Day and HDD = Heating Degree Day, Source: [22].

The available data in the crop budgets for energy use are reported in different units, such as volume (mL, gal, L), weight (oz., $\mathrm{kg}, \mathrm{Mg}$, cwt), units of energy (BTU), and electricity ( $\mathrm{kWh}$ ). To standardize these units, the carbon equivalent (CE) approach [23] and the Farm Energy Analysis Tool (FEAT) [24] were used. The reductions in emissions resulting from the adoption of field and farmstead windbreaks on small (60 ha), medium (300 ha), and large (600 ha) farms were calculated using these values. These estimates were then projected to a 1-million ha basis in each of the farm sizes for comparative purposes.

\subsection{Carbon Emissions for the Major Crops in the United States}

Crop budget data for 58 regional cropping systems, including corn, soybean, potato, and winter wheat, were acquired from Crop Budget sheets [25-34] and summarized in Table A1. Emissions by field management activities (i.e., tillage, seeding, spraying, cultivation, irrigation, harvesting, drying, hauling, and transporting); production, transport, and transfer of fertilizers (nitrogen, phosphorus, potassium, and lime); pesticides (herbicides, fungicides, and insecticides); and crop residue decomposition were converted into CEs [23-25].

Emissions for fertilizers $\left(\mathrm{N}_{2} \mathrm{O}, \mathrm{P}_{2} \mathrm{O}_{5}\right.$, and $\left.\mathrm{K}_{2} \mathrm{O}\right)$ were calculated based on the concentration of minerals, while emissions from pesticides were calculated based on their active ingredient(s), as described on their commercial labels. Fuel emissions were calculated from diesel fuel used by machinery and irrigation pumps. When a pump was powered by electricity, we used the conversion factor of 0.16 to convert $\mathrm{kW} \mathrm{h}^{-1}$ to CE (Table 1) [35]. With this information, potential savings for each crop system were determined based on the $5 \%$ of the area taken out of production by field windbreaks. 
Table 1. Values for converting energy source units to kg of carbon equivalents (kg CE).

\begin{tabular}{ccccc}
\hline Energy Source & Units & BTU & kWh & Mg CE \\
\hline Electricity & kWh & 3412.14 & 1 & 0.000164 \\
Natural gas & Cubic feet & 1030 & 0.30 & 0.000164 \\
Liquefied petroleum gas (LPG) & Gallon & 91,600 & 26.85 & 0.000164 \\
Fuel oil & Gallon & 139,000 & 40.74 & 0.000164 \\
\hline
\end{tabular}

Sources: [21,35].

The data from the Residential Energy Consumption Survey (RECS) were queried from the U.S. Energy Information Administration [21] based on the variables cited in Table A2. Data from five different climatic zones (Zone 1 through Zone 5, Figure 1) were acquired from the U.S. Energy Information Administration (USEIA) [21].

Because new homes consumed $21 \%$ less energy for space heating on average than older homes [21], rural homes over a range of ages (built before and after 2000) were subsampled from the general data. Those years was chosen because the analysis from the EIA's most recent Residential Energy Consumption Survey (RECS) shows that U.S. homes built in 2000 and later consume more energy on average than homes built prior to 2000. From this new database, fifteen variables were analyzed to define the energy used in each climate zone per home type (Table A2).

The energy units of these variables were converted from BTU to $\mathrm{kWh}^{-1}$ and to $\mathrm{Mg} \mathrm{CE}$ using values listed above in Table 1. The conversion from energy sources to CE was based on [35]; protocols for estimating $\mathrm{kg} \mathrm{CE}$ are described in Table A3.

The total CE emissions were calculated for rural homes for all energy sources. Because windbreaks only have a significant effect on energy used for heating and cooling farmsteads, we use only the values for propane and electricity used for heating and cooling homes which can be gathered from RECS data. Although the data were extensive, verified, and of high quality [21], some homes were disqualified based on the following:

- Extreme outliers (more than four standard deviations away from the mean),

- Uninsulated houses,

- Households where the occupants neither owned nor paid rent (i.e., squatted), and

- Farmsteads with wood as the primary source of heat.

It should be noted that many older houses were often inadequately insulated and would benefit greatly from wind protection, but were eliminated from the analysis because they were few in number (less than $1 \%$ ) and their main energy source was wood.

\subsection{Reduced Carbon Emissions in Agricultural Lands by Planting Windbreaks}

Carbon reduction emissions in the cropping area were calculated based on the area removed from production when planted to field windbreaks. To evaluate the effect of the windbreaks on energy savings for farmsteads, it was assumed that:

1. Windbreaks were planted perpendicular to the prevailing wind with conifers and deciduous trees at a canopy density of $40-60 \%$ [36].

2. Energy savings of $10 \%$ for air conditioning [37] and 25\% for home heating [38].

3. An area of 2 ha was defined for both small and medium farms; an area of 3 ha was used for large farms. These farmsteads contained an adequately insulated house of 230 and $270 \mathrm{~m}^{2}$ built before and after 2000, respectively.

4. We used a house built after 2000, due to no significant differences on houses' age (before and after 2000).

5. For full protection of the small and medium farmsteads, a 200-m windbreak was required. For large farms, a 300-m windbreak was required. 
6. In northern zones, a 10-row windbreak is needed while in southern zones a 3-row windbreak is sufficient. Typically, these windbreaks have two sections arranged in an "L-shaped" design and located north and west of the home to protect against winter winds.

7. Three farm sizes were considered: small (60 ha), medium (300 ha), and large (600 ha). This resulted in six scenarios (two age groups of houses and three farm sizes). For calculations, we made some adjustments to the report from United States Department of Agriculture (USDA) Census of Agriculture [39].

\subsection{Data Analysis}

The data were processed under the R environment [40] and Microsoft Excel. The data for the Residential Energy Consumption Survey (RECS) were sub-sampled for rural houses and analyzed for built age (before and after 2000). Descriptive statistics were used for grouping the 58 cropping systems in irrigated and non-irrigated operations across climatic zones to determine their emissions (see Figure 2) and C emissions avoided for each farming scenario.

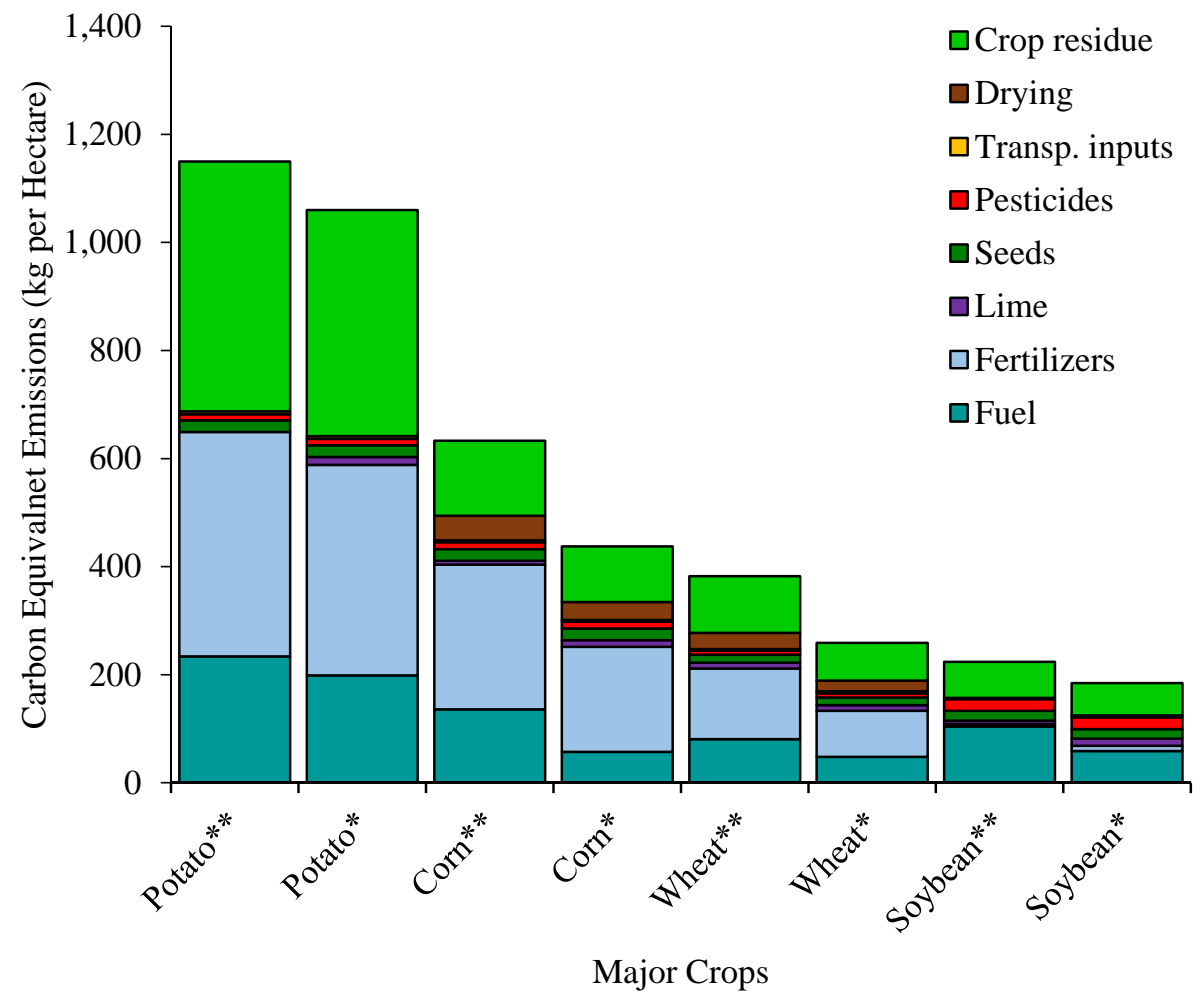

Figure 2. Mean carbon equivalent emissions for the major crops in the nine regions of the United States derived from crop budgets (2017) in the studied areas. ${ }^{* *}=$ irrigated and ${ }^{*}=$ non-irrigated crop systems.

\section{Results}

\subsection{Carbon Emissions for the Major Crops and Farmsteads in the United States}

Carbon emission estimates for the cropping systems used in this study varied among regions and crop systems. These emissions from fossil fuels, fertilizers, herbicides and insecticides, and crop residues ranged from 0.16 to $1.51 \mathrm{Mg} \mathrm{CE} \mathrm{ha}^{-1}$ (Tables A4-A7). Potato systems showed the highest emissions per hectare (1.01 to $1.51 \mathrm{Mg} \mathrm{CE} \mathrm{ha}^{-1}$ ) (Table A4); followed by corn ( 0.25 to $0.81 \mathrm{Mg} \mathrm{CE} \mathrm{ha}^{-1}$ ); winter wheat ( 0.16 to $0.53 \mathrm{Mg} \mathrm{CE} \mathrm{ha}^{-1}$ ); and soybean ( 0.16 to $0.33 \mathrm{Mg} \mathrm{CE} \mathrm{ha}^{-1}$ ). The amount of CEs emitted depends on the farmers' decisions and environmental conditions (Table A1 through Table A7 (e.g., Table A5 Id \#20 and \#21)). Mean CE estimates of the irrigated and non-irrigated crop systems 
are summarized in Figure 2. In these values, the main difference in the energy use comes from diesel fuel and fertilizers in all irrigated crops, especially in potato and corn systems. It follows then that a reduction in the number of hectares farmed significantly reduces the CE emissions from those hectares.

No significant differences in CE emissions were found between houses built before and after 2000. The total CE emissions ranged from 4.5 to 8.1 and 4.1 to $7.4 \mathrm{Mg} \mathrm{CE}_{\text {year }}{ }^{-1}$ per house built before and after 2000, respectively. The emissions by energy source range from 1.4 to $4.1 \mathrm{Mg} \mathrm{CE} \mathrm{year} \mathrm{Mouse}^{-1}$

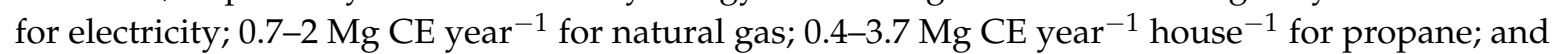
0.0 to $2.5 \mathrm{Mg} \mathrm{CE} \mathrm{year}^{-1}$ house $^{-1}$ for fuel oil (Table 2).

Table 2. Carbon equivalent (CE) emissions for rural houses built before and after 2000 using different energy sources and insulation types in different climatic zones.

\begin{tabular}{|c|c|c|c|c|c|c|c|c|c|c|c|c|c|c|c|c|}
\hline \multirow{3}{*}{$\begin{array}{l}\text { Year } \\
\text { Built }\end{array}$} & \multirow{3}{*}{$\begin{array}{l}\text { Energy } \\
\text { Source }\end{array}$} & \multicolumn{15}{|c|}{ Carbon emissions (Mg CE/year/house) by Climatic Zone and Insulation Type ${ }^{1}$} \\
\hline & & \multicolumn{6}{|c|}{ Northern Regions } & \multirow[b]{2}{*}{$3 W$} & \multirow[b]{2}{*}{$3 \mathbf{A}$} & \multirow[b]{2}{*}{$3 \mathbf{P}$} & \multicolumn{6}{|c|}{ Sothern Regions } \\
\hline & & $1 W$ & $1 \mathrm{~A}$ & $1 P$ & $2 W$ & $2 \mathrm{~A}$ & $2 P$ & & & & $4 W$ & $4 \mathrm{~A}$ & $4 P$ & $5 W$ & $5 \mathrm{~A}$ & $5 P$ \\
\hline \multirow{4}{*}{$<2000$} & Electricity & 1.5 & 1.9 & 2.1 & 1.5 & 1.7 & 1.8 & 2.4 & 2.6 & 2.5 & 2.7 & 2.9 & 3.1 & 3.0 & 4.1 & 4.0 \\
\hline & Natural gas & 1.4 & 1.3 & 2.3 & 1.0 & 1.5 & 1.7 & 1.6 & 1.6 & 1.7 & 1.0 & 1.4 & 1.5 & 0.7 & 1.0 & 1.4 \\
\hline & Propane & 0.9 & 1.2 & 1.9 & 1.3 & 1.5 & 2.2 & 0.9 & 0.8 & 0.9 & 0.8 & 0.7 & 1.1 & 0.8 & 0.4 & 1.1 \\
\hline & Fuel oil & 1.2 & 1.3 & 1.8 & 1.4 & 1.7 & 1.6 & 1.3 & 1.4 & 1.4 & 0.8 & 0.02 & 0.0 & 0.0 & 0.0 & 0.0 \\
\hline \multirow{4}{*}{$>2000$} & Electricity & 1.8 & 1.6 & 1.9 & 1.4 & 1.4 & 2.1 & 2.2 & 2.7 & 3.4 & 2.6 & 2.7 & 2.8 & 2.9 & 2.9 & 3.9 \\
\hline & Natural gas & 2.0 & 1.2 & 1.3 & 1.3 & 1.5 & 1.2 & 1.0 & 1.6 & 2.0 & 1.3 & 1.4 & 1.7 & 1.0 & 0.9 & 0.7 \\
\hline & Propane & 1.1 & 1.3 & 2.0 & 1.3 & 1.5 & 3.7 & 0.9 & 0.8 & 1.1 & 0.8 & 0.7 & 0.9 & 0.7 & 0.3 & 0.9 \\
\hline & Fuel oil $^{2}$ & 2.0 & 1.7 & 2.2 & 1.6 & 2.5 & 0.0 & 0.0 & 0.0 & 0.0 & 0.7 & 0.0 & 0.0 & 0.0 & 0.0 & 0.0 \\
\hline
\end{tabular}

The mean CE emissions for space heating and cooling across regions ranged from 1.4 to $2.3 \mathrm{Mg}$ CE house ${ }^{-1}$ year $^{-1}$ for all age groups (Table 3). As expected, the better the insulation, the lower the CE emitted. Data also indicated northern region homes tended to emit more CE per home than those located in more southern regions. This is most likely due to typical central air conditioners in the south being about four times more energy efficient than a typical furnace or boiler in the north [41].

Table 3. Carbon equivalent emissions for heating and cooling rural houses built before and after 2000 using different energy sources and insulation types in different climatic zones.

\begin{tabular}{|c|c|c|c|c|c|c|c|c|c|c|c|c|c|c|c|c|}
\hline \multirow{3}{*}{$\begin{array}{l}\text { Year } \\
\text { Built }\end{array}$} & \multirow{3}{*}{ Energy Source } & \multicolumn{15}{|c|}{ Total Energy Usage for Heating and Cooling CE Mg } \\
\hline & & \multicolumn{6}{|c|}{ Northern Regions } & \multirow[b]{2}{*}{$3 W$} & \multirow[b]{2}{*}{$3 \mathbf{A}$} & \multirow[b]{2}{*}{$3 \mathbf{P}$} & \multicolumn{6}{|c|}{ Southern Regions } \\
\hline & & $1 W^{1}$ & $\mathbf{1 A}$ & $1 P$ & $2 W$ & $2 \mathrm{~A}$ & $2 \mathbf{P}$ & & & & $4 \mathrm{~W}$ & $4 \mathrm{~A}$ & $4 P$ & $5 W$ & $5 \mathrm{~A}$ & $5 P$ \\
\hline \multirow{4}{*}{$<2000$} & Electricity heating & 0.4 & 0.4 & 0.4 & 0.3 & 0.3 & 0.4 & 0.5 & 0.5 & 0.5 & 0.4 & 0.4 & 0.5 & 0.3 & 0.5 & 0.5 \\
\hline & Electricity cooling & 0.1 & 0.1 & 0.1 & 0.1 & 0.1 & 0.1 & 0.3 & 0.3 & 0.2 & 0.4 & 0.5 & 0.5 & 0.8 & 1.0 & 1.1 \\
\hline & Propane & 1.1 & 1.3 & 1.7 & 1.1 & 1.1 & 1.1 & 0.7 & 0.8 & 0.9 & 0.8 & 0.8 & 1.0 & 0.3 & 0.6 & 0.9 \\
\hline & Total & 1.6 & 1.8 & 2.2 & 1.5 & 1.5 & 1.6 & 1.5 & 1.6 & 1.6 & 1.6 & 1.7 & 2.0 & 1.4 & 2.1 & 2.5 \\
\hline \multirow{4}{*}{$>2000$} & Electricity heating & 0.5 & 0.4 & 0.2 & 0.2 & 0.1 & 0.1 & 0.4 & 0.5 & 0.6 & 0.4 & 0.4 & 0.3 & 0.3 & 0.3 & 0.3 \\
\hline & Electricity cooling & 0.1 & 0.1 & 0.1 & 0.1 & 0.1 & 0.1 & 0.3 & 0.4 & 0.2 & 0.5 & 0.6 & 0.7 & 1.0 & 1.0 & 1.2 \\
\hline & Propane & 0.9 & 1.2 & 1.7 & 1.0 & 1.3 & 1.9 & 0.7 & 0.6 & 0.8 & 0.7 & 0.8 & 0.9 & 0.4 & 0.5 & 0.6 \\
\hline & Total & 1.5 & 1.7 & 2.0 & 1.4 & 1.5 & 2.2 & 1.4 & 1.5 & 1.6 & 1.6 & 1.8 & 1.9 & 1.7 & 1.8 & 2.1 \\
\hline
\end{tabular}

\footnotetext{
${ }^{1}$ Climate Zone (1 to 5), Insulation type: $\mathrm{W}=$ well insulated, $\mathrm{A}=$ adequately insulated, $\mathrm{P}=$ poorly insulated [21].
}

\subsection{Reduction of Emissions by Windbreaks on Agricultural Lands}

Overall, we estimated that the use of field and farmstead windbreaks can reduce emissions from farming operations from a low of $0.01 \mathrm{Mg} \mathrm{CE} \mathrm{ha}^{-1}$ year $^{-1}$ for some windbreak scenarios (e.g., soybean on small Arkansas farms) to a high of $0.7 \mathrm{Mg} \mathrm{CE} \mathrm{ha}^{-1}$ year ${ }^{-1}$ (e.g., large farm scenarios with potato in Massachusetts). Overall, for all farm scenarios considered, the mean reduction in emissions attributable to windbreaks ranged from 0.8 to $39.1 \mathrm{Mg}$ CE for small (60 ha) and large farm (600 ha), 
respectively (Table A8). The lowest reduced emissions occurred in scenarios containing soybean and winter wheat systems, with the highest in potato systems. The mean reduced emissions, for small and large farms, were equivalent to 0.02 to $0.05 \mathrm{Mg} \mathrm{CE} \mathrm{ha}^{-1}$ year $^{-1}$, respectively.

Potato farming scenarios with windbreaks for all regions analyzed had the greatest reduction in emissions. Potato crops are highly intensive in the use of fuel and chemicals, especially nitrogen (Figure 2). These potential reductions for potato systems were estimated to be between 3.3 and $39.1 \mathrm{Mg}$ $\mathrm{CE}$ for small and large farms containing a farmstead. On a per hectare basis, potential reductions in emissions for all farming scenarios with potato and windbreaks were 0.06 and $0.07 \mathrm{Mg} \mathrm{CE} \mathrm{ha}^{-1}$, for small and large potato farms, respectively.

Reduced emissions for corn farming scenarios with windbreaks ranged from 1.2 to $24.7 \mathrm{Mg} \mathrm{CE}$ for small and large farms, respectively. When furrow irrigated, corn on large farms displayed the highest avoided emissions (24.7 Mg CE) (Table A8). This irrigation system includes lower pumping costs per acre-inch of water pumped despite its greater labor costs and lower application efficiency compared to sprinkler and subsurface drip irrigation [42,43]. On a per hectare basis, emissions ranged from 0.02 to $0.04 \mathrm{Mg} \mathrm{CE} \mathrm{ha}^{-1}$ for small and large farms.

Avoided emissions for soybean farming scenarios with windbreaks were 0.8 and 9.6 Mg CE for small and large farms, respectively. The highest emission reduction values occurred in the Corn Belt region (Iowa) for herbicide-tolerant soybean. The lowest reduction of emissions by windbreaks corresponded to non-irrigated soybean in the Corn Belt (Ohio) (Table A8). These reduced CE emission scenarios were equivalent to 0.01 and $0.02 \mathrm{Mg} \mathrm{CE} \mathrm{ha}^{-1}$ for small and large farms, respectively.

Reduction of carbon emissions of windbreaks on winter wheat farming scenarios ranged from 0.9 to $15.6 \mathrm{Mg} \mathrm{CE}$ for small and large farms, respectively. The highest reduction was found in non-irrigated winter wheat under conventional tillage and fallow rotations, while the lowest reduction was found for sprinkler-irrigated continuous wheat in the southern Rocky Mountains region (Colorado). Overall, reduced emissions on these farms were equivalent to 0.02 and $0.03 \mathrm{Mg} \mathrm{CE} \mathrm{ha}^{-1}$.

The CE equivalent emissions for farming scenarios with irrigated and non-irrigated crop systems on small and large farms built after 2000 are summarized in Table 4a. The avoided C emissions after planting windbreaks on $5 \%$ of area of the irrigated and non-irrigated farming scenarios are presented in Table $4 \mathrm{~b}$. Our calculations indicate that windbreaks may have the potential to provide the largest reduction in $\mathrm{C}$ equivalent emissions in irrigated potato systems, while their contributions in the rainfed winter wheat systems were the least. This was most likely due to the large amounts of fertilizer and fuel used in potato systems that were then partially reduced by use of field windbreaks.

From these results, we calculated the potential reduction in $\mathrm{C}$ emissions for a national windbreak program encompassing 1 million ha (2.47 million acres) of agricultural lands. A program designed to establish windbreaks on 17,000 small; 3300 medium; or 1700 large farms would plant approximately 0.05 million ha $(0.12$ million acres) of windbreaks, thereby removing that area from production. Over a year's cropping cycle, emissions ranging from 9660 (non-irrigated soybean system) to 65,363 Mg CE year ${ }^{-1}$ (irrigated potato system) could potentially be avoided on 0.05 million ha (Table 4c). The reductions were equivalent to 0.193 for non-irrigated soybean systems to $1.3 \mathrm{Mg} \mathrm{CE} \mathrm{year}^{-1}$ for irrigated potato systems. During the 50-year lifespan of the windbreaks, we could expect a reduction in emissions on the order of 0.5 and 3.3 Tg CE. 
Table 4. (a) Total carbon equivalent ( $\mathrm{Mg} \mathrm{CE}_{\text {year }}{ }^{\mathbf{- 1}}$ ) emissions estimates for irrigated and non-irrigated farming scenarios on farms containing adequately insulated houses built after 2000; (b) Scenarios for reduced carbon emissions ( $\mathrm{Mg} \mathrm{CE}$ ) on small, medium, and large size farms growing irrigated and non-irrigated crop systems and planting field and farmstead windbreaks; (c) Potential reduction in carbon emissions due to the use of windbreaks for various farming scenarios based on 1 million ha worth of farm at each size.

\begin{tabular}{|c|c|c|c|}
\hline \multirow{3}{*}{ Crop Systems } & \multicolumn{3}{|c|}{ Houses Built after 2000} \\
\hline & Small (60 ha) & Medium (300 ha) & Large (600 ha) \\
\hline & \multicolumn{3}{|c|}{ Mg CE year ${ }^{-1}$} \\
\hline \multicolumn{4}{|c|}{ (a) } \\
\hline Potato ** & 73.1 & 361.3 & 720.4 \\
\hline Potato * & 60.1 & 294.6 & 586.6 \\
\hline Corn ** & 40.2 & 192.2 & 381.5 \\
\hline Corn * & 28.8 & 133.4 & 263.7 \\
\hline Wheat ** & 25.0 & 114.1 & 225.1 \\
\hline Wheat* & 18.5 & 80.4 & 157.6 \\
\hline Soybean $* *$ & 17.6 & 76.1 & 148.9 \\
\hline Soybean * & 14.1 & 58.1 & 112.9 \\
\hline \multicolumn{4}{|c|}{ (b) } \\
\hline Potato $* *$ & 3.79 & 18.20 & 39.15 \\
\hline Potato * & 3.14 & 14.86 & 29.46 \\
\hline Corn $* *$ & 2.14 & 9.74 & 19.21 \\
\hline Corn ${ }^{*}$ & 1.57 & 6.80 & 13.31 \\
\hline Wheat ** & 1.38 & 5.84 & 11.39 \\
\hline Wheat* & 1.05 & 4.15 & 8.01 \\
\hline Soybean ** & 1.01 & 3.94 & 7.58 \\
\hline Soybean * & 0.84 & 3.04 & 5.78 \\
\hline \multicolumn{4}{|c|}{ (c) ${ }^{1}$} \\
\hline Potato ** & $64,139^{2}$ & 60,859 & 60,450 \\
\hline Potato * & 53,121 & 49,693 & 49,264 \\
\hline Corn $* *$ & 36,229 & 32,572 & 32,114 \\
\hline Corn * & 26,526 & 22,737 & 22,263 \\
\hline Wheat ** & 23,351 & 19,519 & 19,040 \\
\hline Wheat* & 17,792 & 13,884 & 13,396 \\
\hline Soybean ** & 17,077 & 13,160 & 12,671 \\
\hline Soybean * & 14,112 & 10,155 & 9660 \\
\hline
\end{tabular}

** Irrigated; ${ }^{*}$ non-irrigated crop systems. ${ }^{1}$ Values based on the number of farms for each size that can be placed within a million ha: 17,000 ha (small), 3300 ha (medium), and 7700 ha (large); ${ }^{2}$ To derive the amount of CE per ha, the total amount of $\mathrm{CE}$ is divided by the number of ha of small, median, or large farms.

\section{Discussion}

Agriculture has been identified as one of the anthropogenic activities that produce substantial amounts of GHGs [44]. At the global, regional, and local scale, agriculture is considered the largest source of anthropogenic $\mathrm{N}_{2} \mathrm{O}$ and $\mathrm{CH}_{4}$ [45], contributing $52 \%$ of global methane and $84 \%$ of global nitrous oxide emissions [46]. Around the world, agricultural systems continue to add $\mathrm{C}$ to the atmosphere by using fossil fuels in machinery, using chemicals and other inputs, and cultivating soil, which results in a dynamic release of C [47]. A global analysis of soil C loss following cultivation of forests or grasslands shows a $20 \%$ reduction of the initial soil organic carbon (SOC), or approximately $1500 \mathrm{~g} \mathrm{~m}^{-2}$ in the top $0.3 \mathrm{~m}$ of the soil [48] and 30\% SOC loss within 20 years following cultivation, with the greatest loss in the first five years [49].

Conversely, agriculture is also an accumulator of $\mathrm{C}$, offsetting losses when the organic matter (OM) accumulates in the soil [49] or when aboveground woody biomass acts either as a semi-permanent sink or is used as an energy source [23,48]. Many studies have estimated that farms are responsible for about $13 \%$ of total global emissions, making it the world's second-largest $C$ source, after energy 
production [23]. After 21st Conference of the Parties (COP21) many countries have committed to trying to hold global warming to no more than $2{ }^{\circ} \mathrm{C}$ above preindustrial levels [50].

Most agro-ecosystems have the potential to store C. Pastures, agroforestry, and forest ecosystems tend to lead in soil $\mathrm{C}$ storage. In some regions, large agricultural areas represent a considerable potential for enhancing the rate of $C$ sequestration through management activities that reverse the effects of cultivation on soil organic carbon (SOC) pools [51]. In these cases, refilling depleted soil $C$ pools via woody biomass production may result in much higher rates of SOC storage than the accumulation of passive soil C [52].

Windbreaks, used in support of agriculture production, not only contribute to GHG mitigation through $C$ storage in woody biomass and soils [53], but also provide additional indirect benefits by: (1) reducing the farm's use of fossil fuels, (2) reducing the energy used for heating and cooling homes and other buildings, (3) reducing the inputs applied to crops and livestock, (4) providing more diversity for wildlife habitat [54], and reducing irrigation needs, which has an significant impact on fresh water use for agriculture [55]. Along with these GHG mitigation services, agroforestry practices also provide numerous adaptive services, including diversifying crop production systems to buffer the income risks associated with climatic variability [56]. Much research remains before reliable information and models can be developed to guide the use and management of these spatially and temporally complex systems that can themselves be impacted by shifting conditions $[57,58]$.

This study provides information specific to just the indirect benefits of windbreaks from avoided $\mathrm{C}$ emissions resulting from the reduced use of fossil fuels and other energy-intensive inputs in these different farming scenarios. By providing protection to different crop systems and farmsteads, windbreaks could cut the use of fuel and agricultural inputs by almost $5 \%$ and reduce the use of energy for heating and cooling farmsteads by $10 \%$ to $25 \%[3,16,59]$.

The potential $\mathrm{C}$ emission reduction value for farms with farmstead windbreaks was greatest in those areas with cold winter winds. However, farmsteads in all regions could potentially derive some level of benefits from properly designed windbreaks. The greatest economic benefit was derived from the energy savings from the reduction in air infiltration rates [3]. These results are corroborated in this study when our savings varied with climate conditions (locations) and the type of insulation.

On small farms the largest proportion of emission avoidance is a result of the farmstead windbreak and the largest proportion of the $\mathrm{C}$ stored is in the farmstead windbreak. Small farm scenarios are therefore more likely to approach $\mathrm{C}$ neutrality, potentially storing and/or avoiding more than they emit, through use of windbreaks.

Further reduction of emissions in such farming operations can be accomplished through inclusion of other activities, such as soil conservation practices [60,61]; optimizing fertilizer use [62-64]; improving irrigation systems [65]; and reducing the energy use in farmsteads [66]. In reality, for a farm operation to approach a net zero emission status, the strategic use of several of these activities will be required, with windbreaks being just one.

The contribution of tress in windbreak arrangements on agricultural lands can indirectly reduce input use through the increase of crop productivity. The literature suggests that windbreaks can increase crop yields levels [67] above what would be necessary to compensate for the area withdrawn from crop production [3]. These authors indicated that this additional production will reduce the rate at which additional crop area will need to be added in the future to meet growing food needs. This could potentially lead to a further reduction in the use of fuel and fertilizer and reductions to atmospheric GHG levels. Adding all these reductions and the potential of windbreak trees to directly store $C$ from the atmosphere [20] through their woody structures, windbreaks seem to be a promising strategy to help mitigate the impact of agriculture on global GHG.

Another aspect is that the greatest effects of trees in windbreaks result in years when the extremes of cold, dry, windy conditions, and/or hot, dry, windy conditions are most prevalent [49]. Moreover, these agroforestry practices are also recognized for reducing soil erosion and increasing crop yields in the case of small grains [68-70]; however, other research indicates no consistent trends in benefits 
to small grains $[71,72]$. These results indicate that the effects of windbreaks on crop yields have no conclusive results; for this reason, more research is needed [73,74]. Despite these appealing results, some uncertainties remain, such as the difference between actual and modeled energy consumption from USDA survey [21], the permanent change from home heating and cooling appliances and energy sources, and the uncertainties of future warming [62].

\section{Conclusions}

The avoided CE emissions from fewer acres farmed and less energy used for heating and cooling the farmstead make windbreaks a promising strategy for reducing the impact of agriculture on greenhouse gas emissions. Reduced emissions on farm scenarios containing windbreaks are highly influenced by home insulation, technological improvements, and cropping systems. In these farming scenarios, windbreaks have the potential to substantially reduce the amount of off-farm inputs used on farming operations and may be able to confer at the same time the added advantages of mitigating other negative externalities of the farming operations such as pollution of water sources by pesticides and fertilizers, as stated by [75].

Acknowledgments: The authors would like to acknowledge financial support through the Institute of International Education (IIE)_Fulbright, Colombia; University of Nariño, Colombia, U.S. Forest Service Agreement \#11-JV-11330152-115; and the Nebraska Agricultural Experiment Station with funding from the McIntire-Stennis Cooperative Forestry program (Accession Number 230910) from the USDA National Institute of Food and Agriculture.

Author Contributions: William Ballesteros-Possú, James R. Brandle, and Michele Schoeneberger conceived and designed the experiments; William Ballesteros-Possú performed the experiments; William Ballesteros, James R. Brandle, and Michele Schoeneberger analyzed the data; Michele Schoeneberger and James R. Brandle contributed reagents/materials/analysis tools; William Ballesteros-Possú, James R. Brandle, and Michele Schoeneberger Possú wrote the paper.

Conflicts of Interest: The authors declare no conflict of interest. The founding sponsors had no role in the design of the study; in the collection, analyses, or interpretation of data; in the writing of the manuscript, and in the decision to publish the results.

\section{Appendix A}

Table A1. Crop systems in different regions and states of the continental United States *.

\begin{tabular}{|c|c|c|c|c|}
\hline Region $^{1}$ & State & Crop & Id $^{2}$ & System Description \\
\hline \multirow{4}{*}{ NLS } & \multirow{4}{*}{ WI } & Corn & 1 & Continuous corn, $155 \mathrm{bu}$. \\
\hline & & Corn & 2 & Corn after soybean, $181 \mathrm{bu}$. \\
\hline & & Soybean & 3 & Soybean after corn, 55 bu. \\
\hline & & Wheat & 4 & No description \\
\hline \multirow{15}{*}{$\mathrm{CB}$} & \multirow{9}{*}{$\mathrm{OH}$} & Corn & 5 & Conservation Tillage (No till) \\
\hline & & Corn & 6 & Conservation Tillage (No till) \\
\hline & & Corn & 7 & Conservation Tillage (No till) \\
\hline & & Soybean & 8 & Conservation Tillage Corn/No-Till RR ${ }^{3}$ Soybean \\
\hline & & Soybean & 9 & Conservation Tillage Corn/No-Till RR Soybean \\
\hline & & Soybean & 10 & Conservation Tillage Corn/No-Till RR Soybean \\
\hline & & Wheat & 11 & Wheat/Corn/No-Till RR Soybeans \\
\hline & & Wheat & 12 & Wheat/Corn/No-Till RR Soybeans \\
\hline & & Wheat & 13 & Wheat/Corn/No-Till RR Soybeans \\
\hline & \multirow{6}{*}{$\mathrm{IO}$} & Corn & 14 & Corn following Corn \\
\hline & & Corn & 15 & Corn following Corn \\
\hline & & Corn & 16 & Corn following Corn \\
\hline & & Soybean & 17 & Herbicide Tolerant Soybeans following Corn (non-irrigated) \\
\hline & & Soybean & 18 & Herbicide Tolerant Soybeans following Corn \\
\hline & & Soybean & 19 & Herbicide Tolerant Soybeans following Corn \\
\hline
\end{tabular}


Table A1. Cont.

\begin{tabular}{|c|c|c|c|c|}
\hline Region $^{1}$ & State & Crop & $\mathrm{Id}^{2}$ & System Description \\
\hline \multirow{6}{*}{ SP } & \multirow{6}{*}{ TX } & Corn & 20 & Corn-GMO Seed, Conventional Till-12 Row, Non-irrigated \\
\hline & & Corn & 21 & Corn for grain, $\mathrm{Bt}^{3}$ Furrow irrigated \\
\hline & & Soybean & 22 & Soybeans, RR ${ }^{4}$, Furrow Irrigated, Following Corn or Sorghum \\
\hline & & Soybean & 23 & Soybeans, Roundup Ready, Sprinkler Irrigated \\
\hline & & Wheat & 24 & Continuous Wheat, Furrow Irrigated \\
\hline & & Wheat & 25 & Continuous Wheat, Sprinkler Irrigated \\
\hline \multirow{6}{*}{ DS } & \multirow{6}{*}{ AR } & Corn & 26 & Stacked gene, Center Pivot Irrigation \\
\hline & & Corn & 27 & Stacked gene, No Irrigation \\
\hline & & Soybean & 28 & RR, Furrow Irrigation \\
\hline & & Soybean & 29 & RR, Center Pivot Irrigation \\
\hline & & Soybean & 30 & $\mathrm{RR}$, no Irrigation \\
\hline & & Wheat & 31 & Table 28-A. Wheat enterprise \\
\hline \multirow{6}{*}{$\mathrm{AP}$} & \multirow{6}{*}{ TE } & Corn & 32 & Non-Irrigated Corn, No-Till \\
\hline & & Corn & 33 & Non-Irrigated Corn, Conventional Tillage \\
\hline & & Corn & 34 & Corn, No-Till, Irrigated, 225 Bushels/Acre Yield \\
\hline & & Soybean & 35 & Non-Irrigated Soybean Budget (No-Till) \\
\hline & & Soybean & 36 & Irrigated Soybean Budget (No-Till) \\
\hline & & Wheat & 37 & Wheat Budget (Conventional Tillage) \\
\hline \multirow{6}{*}{ RMN } & \multirow{6}{*}{$\mathrm{IO}$} & Wheat & 38 & $\begin{array}{l}2013 \text { Eastern Idaho Non-irrigated Hard Red Winter Wheat Following } \\
\text { Summer Fallow }\end{array}$ \\
\hline & & Wheat & 39 & $\begin{array}{l}\text { Table 1. } 2013 \text { Eastern Idaho Non-irrigated Hard White Spring Wheat: Higher } \\
\text { Rainfall Areas. }\end{array}$ \\
\hline & & Wheat & 40 & Table 1. 2013 Irrigated Soft White Winter Wheat for Eastern Idaho. \\
\hline & & Potato $^{4}$ & 41 & $\begin{array}{l}\text { Table 1. } 2013 \text { Irrigated Russet Burbank Commercial Potatoes With Fumigation } \\
\text { and On-Farm Storage for Eastern Idaho: Bannock, Bingham and Power Counties. }\end{array}$ \\
\hline & & Potato & 42 & $\begin{array}{l}\text { Table 1. } 2013 \text { Irrigated Russet Burbank Commercial Potatoes With On-Farm } \\
\text { Storage for Eastern Idaho Northern Region: Bonneville and Madison Counties. }\end{array}$ \\
\hline & & Corn & 43 & Continuous corn \\
\hline \multirow{5}{*}{ RMS } & \multirow{5}{*}{$\mathrm{CO}$} & Corn & 44 & $\begin{array}{l}\text { Table 16. 2013. non-irrigated Corn in North East Colorado, Reduced till in a } \\
\text { two-crop in three year Rotation }\end{array}$ \\
\hline & & Corn & 45 & Table 5. 2013. Irrigated Corn \\
\hline & & Wheat & 46 & $\begin{array}{l}\text { Table 15. } 2013 \text { Estimated Production Costs and Returns-Non-irrigated Winter } \\
\text { Wheat in Northeastern Colorado. Reduced-Till in a Two-Crop in } \\
\text { Three-Year Rotation }\end{array}$ \\
\hline & & Wheat & 47 & $\begin{array}{l}\text { Table 14. 2013. non-irrigated Winter Wheat in Northeastern Colorado, } \\
\text { conventional tillage-Till Wheat - Fallow Rotation }\end{array}$ \\
\hline & & Potato & 48 & $\begin{array}{l}\text { Table 6. } 2013 \text { Estimated Production Costs and Returns - Irrigated Potatoes in } \\
\text { Northeastern Colorado }\left(550 \mathrm{cwt}^{5}\right)\end{array}$ \\
\hline NE & MA & Potato & 49 & no Irrigation \\
\hline \multirow{6}{*}{ NP } & \multirow{6}{*}{ NE } & Corn & 50 & 15. Corn, conventional tillage, continuous, 90 bu yield goal ( $85 \mathrm{bu}$, actual yield \\
\hline & & Corn & 51 & $\begin{array}{l}\text { 22. Corn, Continuous, SmartStax }{ }^{6} \text { RIB Complete, } 190 \text { bu yield goal ( } 180 \mathrm{bu} \text {, } \\
\text { actual yield), canal irrigated, gravity, } 15 \text { acre-inches }\end{array}$ \\
\hline & & Corn & 52 & $\begin{array}{l}\text { 24. Corn, no-till, SmartStax, RIB Complete } 7 \text {, continuous, } 250 \text { bu yield goal } \\
\text { ( } 235 \text { bu, actual yield), pivot irrigated, } 800 \text { GPM } 35 \text { PSI, } 9 \text { acre-inches }\end{array}$ \\
\hline & & Wheat & 53 & $\begin{array}{l}\text { 65. Wheat, no-till after beans, } 100 \text { bu, yield Goal ( } 90 \text { bu actual yield)/Pivot } \\
\text { irrigated, } 800 \text { GPM } 35 \text { PSI, } 8 \text { acre-inches }\end{array}$ \\
\hline & & Wheat & 54 & $\begin{array}{l}\text { 63. Wheat, Clean Till Fallow, } 1 \text { Crop in } 2 \text { year, } 50 \text { bu yield goal ( } 45 \text { bu actual } \\
\text { yield)/non-irrigated }\end{array}$ \\
\hline & & Wheat & 55 & $\begin{array}{l}\text { 65. Wheat, no-till wheat before corn, } 2 \text { crops in } 3 \text { year, } 65 \text { bu yield goal ( } 60 \text { bu } \\
\text { actual yield) non-irrigated }\end{array}$ \\
\hline
\end{tabular}


Table A1. Cont.

\begin{tabular}{|c|c|c|c|c|}
\hline Region $^{1}$ & State & Crop & $\mathrm{Id}^{2}$ & System Description \\
\hline \multirow{3}{*}{ NP } & \multirow{3}{*}{$\mathrm{NE}$} & Soybean & 56 & $\begin{array}{l}\text { 48. Soybeans, tilled seedbed, Roundup Ready®after corn ( } 62 \text { bu actual } \\
\text { yield)/pivot irrigated, } 800 \text { GPM } 35 \text { PSI, } 9 \text { acre-inches }\end{array}$ \\
\hline & & Soybean & 57 & $\begin{array}{l}\text { 47. Soybeans, no-till, Roundup Ready continuous ( } 39 \text { bu actual } \\
\text { yield)/non-irrigated }\end{array}$ \\
\hline & & Soybean & 58 & $\begin{array}{l}\text { 51. Soybeans Roundup Ready, no-till narrow row, continuous ( } 59 \text { bu actual } \\
\text { yield)/pivot irrigated, } 800 \text { GPM } 35 \text { PSI, } 6 \text { acre-inches }\end{array}$ \\
\hline \multicolumn{5}{|c|}{$\begin{array}{l}{ }^{1} \text { Description of the regions: NLS = North Lake States, CB = Corn Belt, SP = Southern Plains, DS = Delta } \\
\text { States,AP = Appalachia, RMN = Rocky Mountain North, RMS = Rocky Mountain South, NE = North East, } \\
\text { NP = Northern Plains ; }{ }^{2} \text { Identifier for each crop system used in the following tables; }{ }^{3} \text { Bacillus thuringiensis (Bt); } \\
{ }^{4} \text { Roundup ready crops (RR): Crops genetically modified to be resistant to the herbicide Roundup [76], }{ }^{5} \text { Potato } \\
\text { units are given in cwt which stands for "centum weight," which is another term for "hundredweight." }{ }^{6} \text { SmartStax: } \\
\text { Brand of genetically modified seed. Includes eight genes artificially added to a plant. The traits include protection } \\
\text { and herbicide tolerance [76]. }{ }^{7} \text { SmartStax RIB complete: all appropriate amount of Refuge seed as farmer need for a } \\
\text { field in the Corn Belt has already been blended into the bag with Bt seed [77]. }\end{array}$} \\
\hline
\end{tabular}

Table A2. Description of variables selected from Energy Information Agency Microdata Code Book.

\begin{tabular}{|c|c|c|}
\hline Number & Variable & Description \\
\hline 1 & HDD30YEAR & Heating degree days, 30-year average $1981-2010$, base $65 \mathrm{~F}$ \\
\hline 2 & CDD30YEAR & Cooling degree days, 30-year average $1981-2010$, base $65 \mathrm{~F}$ \\
\hline 3 & AIA Zone & $\begin{array}{l}\text { 1. Less than } 2000 \mathrm{CDD} \text { and greater than } 7000 \mathrm{HDD} \text {; } \\
\text { 2. Less than } 2000 \mathrm{CDD} \text { and } 5500-7000 \mathrm{HDD} ; \\
\text { 3. Less than } 2000 \mathrm{CDD} \text { and } 4000-5499 \mathrm{HDD} ; \\
\text { 4. Less than } 2000 \mathrm{CDD} \text { and less than } 4000 \mathrm{HDD} ; \\
\text { 5. } 2000 \mathrm{CDD} \text { or more and less than } 4000 \mathrm{HDD}\end{array}$ \\
\hline 4 & YEARMADERANGE & $\begin{array}{l}\text { Year range when housing unit was built: } \\
\text { 1. Before } 1950 \text {; } \\
\text { 2. } 1950 \text { to } 1959 \text {; } \\
\text { 3. } 1960 \text { to } 1969 ; \\
\text { 4. } 1970 \text { to } 1979 ; \\
\text { 5. } 1980 \text { to } 1989 ; \\
\text { 6. } 1990 \text { to } 1999 ; \\
\text { 7. } 2000 \text { to } 2004 \text {; } \\
\text { 8. } 2005 \text { to } 2009\end{array}$ \\
\hline 5 & ADQINSUL & $\begin{array}{l}\text { Level of insulation (respondent reported): } \\
\text { 1. Well Insulated; } \\
\text { 2. Adequately Insulated; } \\
\text { 3. Poorly Insulated; } \\
\text { 4. No Insulation }\end{array}$ \\
\hline 6 & TOTSQFT & $\begin{array}{l}\text { Total square footage (includes all attached garages, all } \\
\text { basements, and finished/heated/cooled attics) }\end{array}$ \\
\hline 7 & BTUELSPH & Electricity usage for space heating, in thousand BTU, 2009 \\
\hline 8 & BTUELCOL & $\begin{array}{l}\text { Electricity usage for air-conditioning, central and window/wall } \\
\text { (room), in thousand BTU, } 2009\end{array}$ \\
\hline 9 & BTUNGSPH & Natural Gas usage for space heating, in thousand BTU, 2009 \\
\hline 10 & BTULPSPH & LPG/Propane usage for space heating, in thousand BTU, 2009 \\
\hline 11 & BTUFOSPH & Fuel Oil usage for space heating, in thousand BTU, 2009 \\
\hline 12 & BTUKERSPH & Kerosene usage for space heating, in thousand BTU, 2009 \\
\hline 13 & TOTALBTUSPH & Total usage for space heating, in thousand BTU, 2009 \\
\hline 14 & TOTALBTUCOL & Total usage for air conditioning, in thousand BTU, 2009 \\
\hline 15 & TOTALBTUOTH & $\begin{array}{l}\text { Total usage for appliances, electronics, lighting, and } \\
\text { miscellaneous uses, in thousand BTU, } 2009\end{array}$ \\
\hline
\end{tabular}

Source: Data from the Residential Energy Consumption Survey (RECS) queried from the U.S. Energy Information Administration [21]. 
Table A3. Description of the protocol to convert different energy sources into kg CE.

\begin{tabular}{|c|c|}
\hline Energy Source & Process to Convert Energy Sources into kg CE \\
\hline Electricity & $\begin{array}{l}\mathrm{kWh} \text { per home } \times 1232 \mathrm{lbs} . \mathrm{CO}_{2} \text { per megawatt-hour generated } \times(1 /(1-0.072)) \mathrm{MWh} \\
\text { generated } / \mathrm{MWh}^{-1 e l i v e r e d ~} \times 1 \mathrm{MWh} / 1000 \mathrm{kWh} \times 1 \text { metric ton } / 2204.6 \mathrm{lb}=\text { metric } \\
\text { tons } \mathrm{CO}_{2} \text { home } \text { h }^{-1} / 1000 * 0.27 \mathrm{~kg} \mathrm{CE} \text {. }\end{array}$ \\
\hline Natural gas & $\begin{array}{l}\text { Cubic feet per home } \times 0.0544 \mathrm{~kg} \mathrm{CO}_{2} \text { cubic foot }^{-1} \times 1 / 1000 \mathrm{~kg} \text { metric ton } \\
\text { tons } \mathrm{CO}_{2} \text { home }^{-1} / 1000 * 0.27 \mathrm{~kg} \mathrm{CE} \text {. }\end{array}$ \\
\hline Liquid petroleum gas & 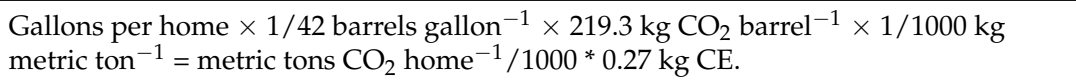 \\
\hline Fuel oil & $\begin{array}{l}\text { Gallons per home } \times 1 / 42 \text { barrels gallon }{ }^{-1} \times 429.61 \mathrm{~kg} \mathrm{CO}_{2} \text { barrel }^{-1} \times 1 / 1000 \mathrm{~kg} \\
\text { metric ton }{ }^{-1}=\text { metric tons } \mathrm{CO}_{2} \text { home }^{-1} / 1000^{*} 0.27 \mathrm{~kg} \mathrm{CE} \text {. }\end{array}$ \\
\hline
\end{tabular}

Table A4. Carbon equivalent emissions for potato systems in the United States.

\begin{tabular}{|c|c|c|c|c|c|c|c|c|c|c|c|c|}
\hline \multirow{2}{*}{ Region } & \multirow{2}{*}{ State } & \multirow{2}{*}{ Id $^{1}$} & \multicolumn{10}{|c|}{ Carbon equivalent emissions (kg CE ha- ${ }^{-1}$ year $^{-1}$ ) } \\
\hline & & & $\mathrm{Bu}^{2}$ & Fuel $^{3}$ & Fertilizers $^{4}$ & Lime & Seed $^{5}$ & Pesticides $^{6}$ & Transport $^{7}$ & Drying ${ }^{8}$ & Residue $^{9}$ & Total \\
\hline \multirow{2}{*}{ RMN } & ID & 41 & 1025.1 & 227.5 & 359.0 & - & 179.8 & 11.4 & 4.6 & - & 484.7 & 1267.0 \\
\hline & & 42 & 864.5 & 233.4 & 328.9 & - & 151.7 & 7.7 & 4.1 & - & 409.9 & 1135.8 \\
\hline \multirow{2}{*}{ RMS } & $\mathrm{CO}$ & 48 & 1358.5 & 142.3 & 471.6 & - & 238.3 & 11.1 & 5.8 & - & 640.0 & 1509.2 \\
\hline & MS & 49 & 741.0 & 225.3 & 281.6 & - & 130.0 & 13.0 & 9.8 & - & 352.4 & 1012.1 \\
\hline
\end{tabular}

${ }^{1}$ Crop system identifier, for more information the reader is refers to Table A1. ${ }^{2}$ Crop yields from crop budgets (2014), these budgets were transformed to bushels ha $(1 \mathrm{ha}=2.47$ acres $) ;{ }^{3}$ Calculated based on diesel fuel. This fuel has an emission factor of 10,180 $\mathrm{g} \mathrm{CO}_{2}$ per gallon and $2.77 \mathrm{~kg} \mathrm{C} \mathrm{gal}^{-1}$ [35]. ${ }^{4}$ Encompass carbon emissions from production, transportation, storage, and distribution of agricultural chemicals: nitrogen (urea), triple super phosphate $\left(\mathrm{P}_{2} \mathrm{O}_{5}\right)$, and potassium sulfate $\left(\mathrm{K}_{2} \mathrm{O}\right)$ [24]. Likewise, $\mathrm{N}_{2} \mathrm{O}$ transfer from synthetic fertilizer [1]. ${ }^{5}$ Carbon emissions calculated based on $\mathrm{kg}$ per ha with a moisture less than $12 \%$ for corn, soybean, and winter wheat and $90 \%$ for potatoes. ${ }^{6}$ Calculations were based on active ingredients of the herbicides, insecticides, and fungicides [24]. ${ }^{7}$ Transport of all inputs from distribution centers and trucking based on 900 bushels loads, $6 \mathrm{mpg}$, oil and lube $10 \%$ of the fuel cost. ${ }^{8}$ Drying cost based on $2.5 \%$ of the moisture removed ( 0.02 gal of Liquefied petroleum gas (LPG) per percent of point of moisture removed), crop moisture at harvest (20\%), and crop moisture at storage (15\%) [24]. ${ }^{9}$ Crop residue based on the amount of carbon released by the plant material remaining after harvesting, including leaves, stalks, and roots [24].

Table A5. Carbon equivalent emissions for corn systems in the United States.

\begin{tabular}{|c|c|c|c|c|c|c|c|c|c|c|c|c|}
\hline \multirow{2}{*}{ Region } & \multirow{2}{*}{ State } & \multirow{2}{*}{ Id } & \multirow{2}{*}{ Bu } & \multicolumn{9}{|c|}{ Carbon Equivalent Emissions (kg CE ha ${ }^{-1}$ year $^{-1}$ ) } \\
\hline & & & & Fuel & Fertilizers & Lime & Seed & Pesticides & Transport & Drying & Residue & Total \\
\hline \multirow[t]{2}{*}{ NLS $^{10}$} & WI & 1 & 383 & 69 & 217 & - & 19 & 11 & 2 & 35 & 107 & 459.9 \\
\hline & & 2 & 447 & 69 & 159 & - & 22 & 8 & 2 & 40 & 123 & 423.6 \\
\hline \multirow[t]{6}{*}{$\mathrm{CB}$} & $\mathrm{OH}$ & 5 & 316 & 48 & 170 & 24 & 16 & 15 & 5 & 29 & 90 & 396.4 \\
\hline & & 6 & 395 & 48 & 210 & 24 & 19 & 15 & 5 & 36 & 110 & 467.3 \\
\hline & & 7 & 474 & 48 & 249 & 24 & 23 & 15 & 6 & 43 & 131 & 539.2 \\
\hline & IA & 14 & 358 & 38 & 242 & - & 18 & 16 & 2 & 32 & 101 & 447.9 \\
\hline & & 15 & 408 & 69 & 243 & - & 20 & 16 & 2 & 37 & 114 & 499.8 \\
\hline & & 16 & 457 & 69 & 244 & - & 23 & 16 & 2 & 41 & 126 & 520.7 \\
\hline \multirow[t]{2}{*}{ SP } & TX & 20 & 247 & 49 & 77 & - & 12 & 16 & 1 & 22 & 72 & 248.6 \\
\hline & & 21 & 494 & 269 & 322 & - & 24 & 17 & 2 & 45 & 136 & 814.8 \\
\hline \multirow[t]{2}{*}{ DS } & AR & 26 & 445 & 66 & 292 & - & 22 & 13 & 3 & 40 & 123 & 558.0 \\
\hline & & 27 & 309 & 66 & 208 & - & 15 & 13 & 2 & 28 & 88 & 419.2 \\
\hline \multirow[t]{3}{*}{$\mathrm{AP}$} & $\mathrm{TN}$ & 32 & 371 & 61 & 225 & 44 & 18 & 10 & 8 & 34 & 104 & 503.8 \\
\hline & & 33 & 371 & 77 & 225 & 44 & 18 & 10 & 8 & 34 & 104 & 519.8 \\
\hline & & 34 & 556 & 78 & 316 & 44 & 27 & 10 & 9 & 50 & 152 & 686.8 \\
\hline RMN & ID & 43 & 378 & 70 & 162 & - & 19 & 6 & 1 & 34 & 106 & 397.1 \\
\hline \multirow[t]{2}{*}{ RMS } & $\mathrm{CO}$ & 44 & 368 & 28 & 158 & - & 18 & 18 & 1 & 33 & 103 & 359.3 \\
\hline & & 45 & 450 & 60 & 192 & - & 22 & 15 & 1 & 41 & 124 & 456.6 \\
\hline \multirow[t]{3}{*}{ NP } & $\mathrm{NE}$ & 50 & 222 & 49 & 125 & - & 11 & 8 & 1 & 20 & 65 & 278.4 \\
\hline & & 51 & 469 & 156 & 203 & - & 23 & 12 & 1 & 42 & 130 & 567.0 \\
\hline & & 52 & 618 & 186 & 280 & - & 30 & 11 & 2 & 56 & 168 & 734.2 \\
\hline
\end{tabular}

${ }^{10}$ Northern Lake States under continuous corn, not irrigated, source [34]. We use 8.2 gal of diesel fuel emitting $22.9 \mathrm{~kg} \mathrm{CE}$ per acre, $166 \mathrm{~kg} \mathrm{~N}, 59.8 \mathrm{~kg} \mathrm{~K}_{2} \mathrm{O}$, and $39 \mathrm{~kg} \mathrm{P}_{2} \mathrm{O}_{5}, 2$ pints of Harnes, 4 ounces of Hornet WDG /acre. This crop system emits $459.9 \mathrm{~kg}$ CE per hectare. 
Table A6. Carbon equivalent emissions for wheat systems in the United States.

\begin{tabular}{|c|c|c|c|c|c|c|c|c|c|c|c|c|}
\hline \multirow{2}{*}{ Region } & \multirow{2}{*}{ State } & \multirow{2}{*}{ Id } & \multirow{2}{*}{ Bu } & \multicolumn{9}{|c|}{ Carbon Equivalent Emissions (kg CE ha ${ }^{-1}$ year $^{-1}$ ) } \\
\hline & & & & Fuel & Fertilizers & Lime & Seed & Pesticides & Transport & Drying & Residue & Total \\
\hline NLS & WI & 4 & 197.6 & 67.1 & 99.3 & - & 28.2 & 7.7 & 3.1 & 27.7 & 96.3 & 329.4 \\
\hline \multirow[t]{3}{*}{$\mathrm{CB}$} & $\mathrm{OH}$ & 11 & 143.3 & 38.5 & 74.4 & 24.0 & 20.5 & 7.7 & 6.1 & 20.1 & 71.7 & 262.9 \\
\hline & & 12 & 177.8 & 38.5 & 54.4 & 24.0 & 25.4 & 7.7 & 6.1 & 24.9 & 87.3 & 268.3 \\
\hline & & 13 & 212.4 & 37.9 & 59.0 & 24.0 & 30.3 & 7.7 & 6.1 & 29.7 & 103.0 & 297.8 \\
\hline \multirow[t]{2}{*}{ SP } & TX & 24 & 148.2 & 41.3 & 81.4 & - & 21.2 & 7.7 & 2.6 & 20.7 & 73.8 & 248.8 \\
\hline & & 25 & 160.6 & 54.4 & 81.4 & - & 22.9 & 7.7 & 2.6 & 22.5 & 79.5 & 271.1 \\
\hline DS & $\mathrm{AR}$ & 31 & 148.2 & 53.9 & 155.0 & - & 21.2 & 7.7 & 3.3 & 20.7 & 73.8 & 335.5 \\
\hline $\mathrm{AP}$ & $\mathrm{TN}$ & 37 & 148.2 & 73.7 & 106.0 & 43.6 & 21.2 & 7.7 & 8.9 & 20.7 & 73.8 & 355.6 \\
\hline \multirow[t]{3}{*}{$\mathrm{RMN}$} & ID & 38 & 88.9 & 48.1 & 64.9 & - & 12.7 & 7.7 & 2.3 & 12.4 & 47.0 & 195.1 \\
\hline & & 39 & 123.5 & 43.4 & 115.8 & - & 17.6 & 7.7 & 2.6 & 17.3 & 62.7 & 267.0 \\
\hline & & 40 & 308.8 & 62.8 & 194.0 & - & 44.1 & 7.7 & 3.1 & 43.2 & 146.7 & 501.6 \\
\hline \multirow[t]{2}{*}{ RMS } & $\mathrm{CO}$ & 46 & 86.5 & 34.9 & 54.1 & - & 12.4 & 7.7 & 2.2 & 12.9 & 48.3 & 172.4 \\
\hline & & 47 & 71.6 & 45.1 & 42.6 & - & 10.2 & 7.7 & 2.1 & 9.8 & 38.3 & 155.8 \\
\hline \multirow[t]{3}{*}{ NP } & NE & 53 & 247.0 & 165.0 & 165.3 & - & 35.3 & 7.7 & 2.8 & 34.6 & 118.7 & 529.4 \\
\hline & & 54 & 123.5 & 52.9 & 78.0 & - & 17.6 & 7.7 & 2.4 & 17.3 & 62.7 & 238.6 \\
\hline & & 55 & 148.2 & 43.5 & 115.4 & - & 21.2 & 7.7 & 2.6 & 20.7 & 73.8 & 285.0 \\
\hline
\end{tabular}

Table A7. Carbon equivalent emissions for soybean systems in the United States.

\begin{tabular}{|c|c|c|c|c|c|c|c|c|c|c|c|c|}
\hline \multirow{2}{*}{ Region } & \multirow{2}{*}{ State } & \multirow{2}{*}{ Id } & \multirow{2}{*}{$\mathbf{B u}$} & \multicolumn{9}{|c|}{ Carbon Equivalent Emissions (kg CE ha- ${ }^{-1}$ year $^{-1}$ ) } \\
\hline & & & & Fuel & Fertilizers & Lime & Seed & Pesticides & Transport & Drying & Residue & Total \\
\hline NLS & WI & 3 & 136 & 60.9 & 29.7 & - & 34.0 & 17.9 & 1.8 & - & 64.7 & 209.0 \\
\hline \multirow[t]{6}{*}{$\mathrm{CB}$} & $\mathrm{OH}$ & 8 & 91 & 27.5 & 8.6 & 24.0 & 22.8 & 22.5 & 5.1 & - & 58.2 & 168.7 \\
\hline & & 9 & 116 & 27.5 & 8.6 & 24.0 & 29.0 & 22.5 & 5.1 & - & 58.2 & 174.9 \\
\hline & & 10 & 138 & 27.5 & 10.3 & 24.0 & 34.6 & 22.5 & 5.2 & - & 65.5 & 189.6 \\
\hline & IA & 17 & 111 & 86.5 & 8.6 & - & 27.8 & 23.0 & 1.7 & - & 56.5 & 204.1 \\
\hline & & 18 & 124 & 87.2 & 9.6 & - & 30.9 & 23.0 & 1.8 & - & 60.6 & 213.0 \\
\hline & & 19 & 136 & 88.2 & 10.5 & - & 34.0 & 23.1 & 1.8 & - & 64.7 & 222.2 \\
\hline \multirow[t]{2}{*}{ SP } & TX & 22 & 148 & 178.5 & 5.1 & - & 37.1 & 21.1 & 1.3 & - & 68.7 & 311.7 \\
\hline & & 23 & 148 & 137.5 & 5.1 & - & 37.1 & 21.1 & 1.3 & - & 68.7 & 270.8 \\
\hline \multirow[t]{3}{*}{ DS } & $\mathrm{AR}$ & 28 & 124 & 56.9 & 8.5 & - & 30.9 & 22.5 & 1.7 & - & 60.6 & 181.1 \\
\hline & & 29 & 124 & 58.5 & 8.5 & - & 30.9 & 22.5 & 1.7 & - & 60.6 & 182.6 \\
\hline & & 30 & 74 & 58.5 & 8.5 & - & 18.5 & 22.5 & 1.7 & - & 45.4 & 155.1 \\
\hline \multirow[t]{2}{*}{$\mathrm{AP}$} & $\mathrm{TN}$ & 35 & 111 & 54.5 & 4.9 & 43.6 & 27.8 & 21.4 & 7.6 & - & 56.5 & 216.4 \\
\hline & & 36 & 148 & 54.5 & 4.9 & 43.6 & 37.1 & 21.4 & 7.6 & - & 68.7 & 237.8 \\
\hline \multirow[t]{3}{*}{ NP } & $\mathrm{NE}$ & 56 & 153 & 196.3 & - & - & 38.3 & 21.4 & 1.0 & - & 70.4 & 327.4 \\
\hline & & 57 & 96 & 68.2 & - & - & 24.1 & 21.4 & 1.0 & - & 70.4 & 185.0 \\
\hline & & 58 & 146 & 187.5 & - & - & 36.4 & 21.4 & 1.0 & - & 70.4 & 316.7 \\
\hline
\end{tabular}

Table A8. Potential of windbreaks on different faming scenarios for avoiding carbon emissions.

\begin{tabular}{|c|c|c|c|c|c|c|c|c|c|c|}
\hline \multirow{4}{*}{ Region } & \multirow{4}{*}{ State } & \multirow{4}{*}{$\begin{array}{l}\text { Crop } \\
\text { System }\end{array}$} & \multirow{4}{*}{$\begin{array}{l}\text { System } \\
\text { Code }\end{array}$} & \multirow{4}{*}{$\begin{array}{l}\text { Climatic } \\
\text { Zone }\end{array}$} & \multicolumn{6}{|c|}{ Scenarios for Avoided Emissions (Mg CE year $\left.^{-1}\right)^{1}$} \\
\hline & & & & & \multirow{2}{*}{\multicolumn{3}{|c|}{$\begin{array}{c}\text { House Built before } 2000 \\
\text { Farm Size (ha) }^{2}\end{array}$}} & \multirow{2}{*}{\multicolumn{3}{|c|}{$\begin{array}{c}\text { House Built after } 2000 \\
\text { Farm Size (ha) }\end{array}$}} \\
\hline & & & & & & & & & & \\
\hline & & & & & $\begin{array}{c}\text { Small } \\
(60)\end{array}$ & $\begin{array}{l}\text { Medium } \\
(300)\end{array}$ & $\begin{array}{l}\text { Large } \\
(600)\end{array}$ & $\begin{array}{c}\text { Small } \\
(60)\end{array}$ & $\begin{array}{l}\text { Medium } \\
(300)\end{array}$ & $\begin{array}{l}\text { Large } \\
(600)\end{array}$ \\
\hline \multirow[t]{4}{*}{ NLS } & WI & Corn & 1 & 1 & 1.93 & 7.4 & 14.3 & 1.7 & 7.3 & 14.2 \\
\hline & & Corn & 2 & 1 & 1.7 & 6.8 & 13.2 & 1.6 & 6.7 & 13.0 \\
\hline & & Soybean & 3 & 1 & 1.1 & 3.4 & 6.3 & 1.0 & 3.3 & 6.1 \\
\hline & & Wheat & 4 & 1 & 1.4 & 5.2 & 9.9 & 1.3 & 5.2 & 9.8 \\
\hline \multirow[t]{9}{*}{$\mathrm{CB}$} & $\mathrm{OH}$ & Corn & 5 & 2 & 1.6 & 6.4 & 12.4 & 1.5 & 6.4 & 12.4 \\
\hline & & Corn & 6 & 2 & 1.8 & 7.4 & 14.4 & 1.7 & 7.4 & 14.4 \\
\hline & & Corn & 7 & 2 & 2.0 & 8.4 & 16.4 & 1.9 & 8.4 & 16.4 \\
\hline & & Soybean & 8 & 2 & 0.9 & 2.8 & 5.3 & 0.8 & 2.8 & 5.2 \\
\hline & & Soybean & 9 & 2 & 0.9 & 2.8 & 5.3 & 0.8 & 2.8 & 5.2 \\
\hline & & Soybean & 10 & 2 & 0.9 & 3.0 & 5.6 & 0.9 & 2.9 & 5.5 \\
\hline & & Wheat & 11 & 2 & 1.1 & 4.2 & 8.1 & 1.1 & 4.2 & 8.0 \\
\hline & & Wheat & 12 & 2 & 1.1 & 4.2 & 8.1 & 1.1 & 4.2 & 8.0 \\
\hline & & Wheat & 13 & 2 & 1.2 & 4.6 & 8.8 & 1.2 & 4.6 & 8.8 \\
\hline
\end{tabular}


Table A8. Cont.

\begin{tabular}{|c|c|c|c|c|c|c|c|c|c|c|}
\hline \multirow{4}{*}{ Region } & \multirow{4}{*}{ State } & \multirow{4}{*}{$\begin{array}{c}\text { Crop } \\
\text { System }\end{array}$} & \multirow{4}{*}{$\begin{array}{l}\text { System } \\
\text { Code }\end{array}$} & \multirow{4}{*}{$\begin{array}{c}\text { Climatic } \\
\text { Zone }\end{array}$} & \multicolumn{6}{|c|}{ Scenarios for Avoided Emissions (Mg CE year $\left.^{-1}\right)^{1}$} \\
\hline & & & & & \multirow{2}{*}{\multicolumn{3}{|c|}{$\begin{array}{c}\text { House Built before } 2000 \\
\text { Farm Size (ha) }^{2}\end{array}$}} & \multirow{2}{*}{\multicolumn{3}{|c|}{$\begin{array}{c}\text { House Built after } 2000 \\
\text { Farm Size (ha) }\end{array}$}} \\
\hline & & & & & & & & & & \\
\hline & & & & & $\begin{array}{c}\text { Small } \\
(60)\end{array}$ & $\begin{array}{l}\text { Medium } \\
(300)\end{array}$ & $\begin{array}{c}\text { Large } \\
(600)\end{array}$ & $\begin{array}{c}\text { Small } \\
(60)\end{array}$ & $\begin{array}{l}\text { Medium } \\
(300)\end{array}$ & $\begin{array}{c}\text { Large } \\
(600)\end{array}$ \\
\hline \multirow{13}{*}{ SP } & \multirow[t]{6}{*}{ IA } & Corn & 14 & 2 & 1.7 & 7.1 & 13.9 & 1.7 & 7.1 & 13.9 \\
\hline & & Corn & 15 & 2 & 1.9 & 7.9 & 15.4 & 1.8 & 7.8 & 15.3 \\
\hline & & Corn & 16 & 2 & 1.9 & 8.1 & 15.9 & 1.9 & 8.1 & 15.9 \\
\hline & & Soybean & 17 & 2 & 1.0 & 3.3 & 6.2 & 0.9 & 3.3 & 6.2 \\
\hline & & Soybean & 18 & 2 & 1.0 & 3.4 & 6.4 & 0.9 & 3.3 & 6.3 \\
\hline & & Soybean & 19 & 2 & 1.0 & 3.5 & 6.6 & 1.0 & 3.4 & 6.5 \\
\hline & \multirow[t]{7}{*}{$\mathrm{TX}$} & Corn & 20 & 5 & 1.2 & 4.3 & 8.1 & 1.0 & 4.1 & 7.9 \\
\hline & & Corn & 21 & 5 & 2.8 & 12.5 & 24.7 & 2.6 & 12.3 & 24.5 \\
\hline & & Soybean & 22 & 5 & 1.3 & 4.8 & 9.1 & 1.1 & 4.6 & 9.0 \\
\hline & & Soybean & 19 & 2 & 1.1 & 4.2 & 7.9 & 1.0 & 4.0 & 7.7 \\
\hline & & Soybean & 23 & 5 & 1.1 & 4.0 & 7.6 & 0.9 & 3.8 & 7.5 \\
\hline & & Wheat & 24 & 5 & 1.2 & 4.3 & 8.3 & 1.0 & 4.1 & 8.1 \\
\hline & & Wheat & 25 & 5 & 1.2 & 4.3 & 8.1 & 1.0 & 4.1 & 7.9 \\
\hline \multirow[t]{6}{*}{ DS } & \multirow[t]{6}{*}{ AR } & Corn & 26 & 4 & 1.9 & 8.6 & 17.0 & 2.0 & 8.7 & 17.0 \\
\hline & & Corn & 27 & 4 & 1.5 & 6.7 & 13.0 & 1.6 & 6.7 & 13.1 \\
\hline & & Soybean & 28 & 4 & 0.8 & 2.8 & 5.3 & 0.8 & 2.9 & 5.4 \\
\hline & & Soybean & 29 & 4 & 0.8 & 2.8 & 5.4 & 0.8 & 2.9 & 5.4 \\
\hline & & Soybean & 30 & 4 & 0.8 & 2.6 & 4.9 & 0.8 & 2.7 & 5.0 \\
\hline & & Wheat & 31 & 4 & 1.3 & 5.2 & 10.1 & 1.3 & 5.3 & 10.2 \\
\hline \multirow[t]{6}{*}{ AP } & \multirow[t]{6}{*}{$\mathrm{TN}$} & Corn & 32 & 4 & 1.8 & 7.9 & 15.5 & 1.8 & 7.9 & 15.5 \\
\hline & & Corn & 33 & 4 & 1.8 & 8.1 & 15.9 & 1.9 & 8.2 & 16.0 \\
\hline & & Corn & 34 & 4 & 2.3 & 10.5 & 20.6 & 2.3 & 10.5 & 20.7 \\
\hline & & Soybean & 35 & 4 & 0.9 & 3.4 & 6.5 & 1.0 & 3.4 & 6.5 \\
\hline & & Soybean & 36 & 4 & 0.9 & 3.6 & 6.8 & 1.0 & 3.6 & 6.9 \\
\hline & & Wheat & 37 & 4 & 1.3 & 5.5 & 10.7 & 1.4 & 5.6 & 10.8 \\
\hline \multirow[t]{6}{*}{ RMN } & \multirow[t]{6}{*}{ ID } & Wheat & 38 & 1 & 1.1 & 3.5 & 6.4 & 1.0 & 3.3 & 6.3 \\
\hline & & Wheat & 39 & 1 & 1.3 & 4.5 & 8.4 & 1.2 & 4.3 & 8.3 \\
\hline & & Wheat & 40 & 1 & 1.9 & 7.6 & 14.6 & 1.8 & 7.4 & 14.5 \\
\hline & & Potato & 41 & 1 & 3.7 & 17.0 & 33.6 & 3.6 & 16.9 & 33.5 \\
\hline & & Potato & 42 & 1 & 3.4 & 15.5 & 30.5 & 3.3 & 15.4 & 30.4 \\
\hline & & Corn & 43 & 1 & 1.7 & 6.5 & 12.5 & 1.6 & 6.4 & 12.3 \\
\hline \multirow[t]{5}{*}{ RMS } & \multirow[t]{5}{*}{$\mathrm{CO}$} & Corn & 44 & 1 & 1.6 & 5.9 & 11.4 & 1.4 & 5.8 & 11.2 \\
\hline & & Corn & 45 & 1 & 1.8 & 7.3 & 14.1 & 1.7 & 7.2 & 14.0 \\
\hline & & Wheat & 46 & 1 & 1.0 & 3.1 & 5.7 & 0.9 & 3.0 & 5.6 \\
\hline & & Wheat & 47 & 1 & 1.0 & 2.9 & 5.3 & 0.9 & 2.8 & 5.2 \\
\hline & & Potato & 48 & 1 & 4.3 & 19.8 & 39.1 & 4.1 & 19.7 & 39.0 \\
\hline $\mathrm{NE}$ & MA & Potato & 49 & 1 & 3.3 & 14.6 & 28.8 & 3.1 & 14.5 & 28.7 \\
\hline NP & $\mathrm{NE}$ & Corn & 50 & 2 & 1.2 & 4.7 & 9.0 & 1.2 & 4.7 & 9.0 \\
\hline & & Corn & 51 & 2 & 2.0 & 8.8 & 17.3 & 2.0 & 8.8 & 17.2 \\
\hline & & Corn & 52 & 2 & 2.5 & 11.2 & 22.1 & 2.5 & 11.2 & 22.0 \\
\hline & & Wheat & 53 & 2 & 1.9 & 8.0 & 15.6 & 1.8 & 7.9 & 15.5 \\
\hline & & Wheat & 54 & 2 & 1.1 & 3.9 & 7.4 & 1.0 & 3.9 & 7.4 \\
\hline & & Wheat & 55 & 2 & 1.2 & 4.5 & 8.7 & 1.2 & 4.5 & 8.7 \\
\hline & & Soybean & 56 & 2 & 1.3 & 5.0 & 9.6 & 1.2 & 4.9 & 9.5 \\
\hline & & Soybean & 57 & 2 & 0.9 & 3.1 & 5.7 & 0.9 & 3.0 & 5.7 \\
\hline & & Soybean & 58 & 2 & 1.3 & 4.8 & 9.3 & 1.2 & 4.8 & 9.3 \\
\hline
\end{tabular}

${ }^{1}$ Values from CE emissions for different cropping systems and energy used for heating and cooling of adequately insulated farmstead houses. Reduced CE emissions for crop system were calculated in the $5 \%$ of the agricultural land taken out from crops by field windbreaks while in farmstead the effect of windbreaks in the reduction of CE emissions for space heating was $25 \%$ and for air conditioning $10 \%{ }^{2}$ The calculations for farm size were 58,178 , and 597 ha for small, medium, and large farm, respectively. To obtain the value for ha, divide for these values; the value comes from $5 \%$ of the corn emissions (Table A5, Id. 1) of a small farm located in climate zone 1, emitting $26.85 \mathrm{Mg}$ CE $(0.463 \times 58), 25 \%$ and $10 \%$ of the reduced emissions for space heating and cooling, respectively, in an adequately insulated farmstead built before 2000 (Table 3).

\section{References}

1. IPCC. Climate Change: The Physical Science Basis. Contribution of Working Group I to the Fifth Assessment Report of the Intergovernmental Panel on Climate Change. Chapter 8, Anthropogenic and Natural. 2013. Available online: https://www.ipcc.ch/pdf/assessment-report/ar5/wg1/WG1AR5_Frontmatter_FINAL. pdf (accessed on 14 February 2017). 
2. Schoeneberger, M.M.; Bentrup, G.; de Gooijer, H.; Soolanayakanahally, R.; Sauer, T.; Brandle, R.J.; Zhou, X.; Current, D. Branching out: Agroforestry as a climate change mitigation and adaptation tool for agriculture. Soil Water Conserv. 2012, 67, 128-136. [CrossRef]

3. Brandle, J.R.; Wardle, T.D.; Bratton, G.F. Opportunities to increase tree planting in shelterbelts and the potential impacts on carbon storage and conservation. In Forests and Global Change; Opportunities for Increasing Forest Cover; Coomes, D.A., Burslem, D.F.R.P., Simonson, W.D., Eds.; American Forests: Washington, DC, USA, 1992; Volume 1, pp. 157-176.

4. Caborn, J.M. Shelterbelts and Microclimate; Forestry Commission. Bulletin No. 29; Department of Forestry, University of Edinburgh: Edinburgh, UK, 1957; p. 135.

5. Stoeckler, J.H. Shelterbelt Influence on Great Plains Field Environment and Crops; Forest Service Product, Research Paper; USDA: Washington, DC, USA, 1962; Volume 62, p. 2.

6. Van Eimern, J.; Karscho, R.; Razumova, L.A.; Roberston, G.W. Windbreaks and Shelterbelts; Technical Note No. 59; World Meteorological Organization: Geneva, Switzerland, 1964; p. 188.

7. Grace, J. Plant response to wind. Agric. Ecosyst. Environ. 1988, 22, 71-88. [CrossRef]

8. Kort, J. Benefits of windbreaks to field and forage crops. Agric. Eco. Environ. 1998, 22, 165-190.

9. Sun, D.; Dickinson, G.R. Wind effect on windbreak establishment in Northern Australia. Tree Plant. Notes 1994, 45, 72-75.

10. Hodges, L.; Suratman, M.N.; Brandle, J.R.; Hubbard, K.G. Growth and yield of snap beans as affected by wind protection and microclimate manages due to shelterbelts and planting dates. Hort. Sci. 2004, 39, 996-1004.

11. Brandle, J.R.; Hodges, L.; Tyndall, J.; Sudmeyer, R.A. Windbreak practices. In North American Agroforestry, an Integrated Science and Practice, 2nd ed.; Garrett, H.E., Ed.; American Society of Agronomy: Madison, WI, USA, 2009; pp. 75-104.

12. Shaw, D.L. The design and use of living snow fences in North America. Agric. Ecosyst. Environ. 1988, 22, 351-362. [CrossRef]

13. Scholten, H. Snow distribution on crop fields. Agric. Ecosyst. Environ. 1988, 22, 363-380. [CrossRef]

14. Mattingly, G.E.; Harrje, D.T.; Heisler, G.M. The effectiveness of an evergreen windbreak for reducing residential energy consumption. ASHRAE Trans. 1979, 85, 428-443.

15. Harrje, D.T.; Buckley, C.E.; Heisler, G.M. Building energy reductions: Windbreak optimization. J. Energy Div. Am. Soc. Civ. Eng. 1981, 108, 143-154.

16. DeWalle, D.R.; Heisler, G.M. Use of windbreaks for home energy conservation. Agric. Ecosyst. Environ. 1988, 22, 243-260. [CrossRef]

17. Moyer, R.L. Shelterbelt benefit to home heating cost. Trans. ASAE 1999, 33, 2-10.

18. USDA National Agroforestry Centre (USDA-NAC). Windbreaks. Available online: http://nac.unl.edu/ practices/windbreaks.htm (accessed on 14 February 2017).

19. Ballesteros, P.W.; Brandle, J.R.; Domke, G.; Schoeneberger, M.; Blankenship, E. Estimating carbon storage in windbreak trees on U.S. agricultural lands. Agrofor. Syst. 2016, 90, 889-904.

20. Helmers, G.A.; Brandle, J. Optimum Windbreak Spacing in Great Plains Agriculture (2005). Great Plains Res. 2005, 15, 179-198.

21. US Energy Information Administration (USEIA). Residential Energy Consumption Survey, Microdata (RECS). Available online: http:/ / www.eia.gov/consumption/residential/data/2009/index.cfm?view=microdata (accessed on 14 February 2017).

22. US Energy Information Administration (USEIA). Residential Energy Consumption Survey, Maps: (RECS). Available online: http:/ / www.eia.gov/consumption/residential/data/2009/index.cfm?view=microdata (accessed on 14 February 2017).

23. Lal, R. Carbon emission from farm operations. Environ. Int. 2004, 30, 981-990. [CrossRef] [PubMed]

24. Camargo, G.T.; Ryan, M.R.; Richard, T.L. Energy use and greenhouse gas emissions from crop production using the farm energy analysis tool. BioScience 2013, 63, 263-273.

25. University of Colorado. Crop Enterprise Budgets. Available online: http://www.coopext.colostate.edu/ abm/cropbudgets.htm (accessed on 14 February 2017).

26. University of Idaho. Crop Budgets. Available online: http://web.cals.uidaho.edu/idahoagbiz/enterprisebudgets/ (accessed on 14 February 2017). 
27. University of Iowa. Estimated Costs of Crop Production in Iowa-2017. Available online: http://www. extension.iastate.edu/agdm/crops/pdf/a1\&\#x2013;20.pdf (accessed on 14 February 2017).

28. University of Kansas. Crop Budges, Sheets Budgets. Available online: http:/ /www.sedgwick.k-state.edu/ agriculture/crops/crop-budget-sheets.html (accessed on 14 February 2017).

29. University of Montana. Crops Cost of Production. Available online: http://www.montana.edu/ softwaredownloads/cropdownloads.html (accessed on 14 February 2017).

30. University of Nebraska (Klein, N.R.). Nebraska Crop Budgets. Available online: http://cropwatch.unl.edu/ budgets (accessed on 14 February 2017).

31. University of Ohio. Research: Farm Management Enterprise Budgets. Available online: http://aede.osu. edu/research/osu-farm-management/enterprise-budgets (accessed on 14 February 2017).

32. University of Tennessee. Field Crop Budgets. Available online: http:/ / economics.ag.utk.edu/budgets.html (accessed on 14 February 2017).

33. University of Texas. Crops and Livestock Budgets. Available online: http://agecoext.tamu.edu/resources / crop-livestock-budgets / (accessed on 14 February 2017).

34. University of Wisconsin. Enterprise Budgets: Field Crop Enterprise Budgets for 2014. Available online: http:/ / www.uwex.edu/ces/farmteam/budgets/fieldcrop.cfm (accessed on 14 February 2017).

35. US Environmental Protection Agency (USEPA). Calculations and References. Available online: https:/ / www.epa.gov/energy/greenhouse-gases-equivalencies-calculator-calculations-and-references (accessed on 14 February 2017).

36. Brandle, J.R.; Hintz, D.L.; Sturrock, J.W. (Eds.) Windbreak Technology; Elsevier Science Publishers: Amsterdam, The Netherlands, 1988; p. 598.

37. McPherson, E.G. Using urban forests for energy efficiency and C storage. J. For. 1994, 94, 36-41.

38. McPherson, E.G. Energy-saving potential of trees in Chicago. In Chicago's Urban Forest Ecosystem: Results of the Chicago Urban Forest Climate Project; General Technical Report; USDA Forest service: Davis, CA, USA, 1994; p. 210.

39. USDA. Census of the Agriculture: Highlights, Preliminary Report: U.S. Farms and Farmers. Available online: https://www.agcensus.usda.gov/Publications/2012/Preliminary_Report/Highlights.pdf (accessed on 2 April 2017).

40. Comprehensive R Archival Network (CRAN). R Project. Available online: http:/ / cran.r-project.org (accessed on 14 February 2017).

41. Sivak, M. Air conditioning versus heating: Climate control is more energy demanding in Minneapolis than in Miami. Environ. Res. Lett. 2013, 8, 1-4. [CrossRef]

42. Elliott, R.L.; Walker, W.R. Field evaluation of furrow infiltration and advance functions. Trans. ASAE 1982, 25, 396-400. [CrossRef]

43. Yonts, C.D.; Eisenhauer, D.E.; Varner, D.L. Managing Furrow Irrigation Systems. Available online: http:/ / extensionpublications.unl.edu/assets/html/g1338/build/g1338.htm (accessed on 14 February 2017).

44. IPCC. Climate Change 2014: Mitigation of Climate Change. Contribution of Working Group III to the Fifth Assessment Report of the Intergovernmental Panel on Climate Change; Edenhofer, O., Pichs-Madruga, R., Sokona, Y., Farahani, E., Kadner, S., Seyboth, K., Adler, A., Baum, I., Brunner, S., Eickemeier, P., Eds.; Cambridge University Press: Cambridge, UK; New York, NY, USA, 2014; Available online: http://www.ipcc.ch/pdf/ assessment-report/ar5/wg3/ipcc_wg3_ar5_full.pdf (accessed on 2 April 2017).

45. McMichael, A.J.; Powles, J.W.; Butler, C.D.; Uauy, R. Food, livestock production, energy, climate change, and health. Lancet 2007, 370, 1253-1263. [CrossRef]

46. Mann, L.K. Changes in soil C storage after cultivation. Soil Sci. 1986, 142, 279-288. [CrossRef]

47. Davidson, E.A.; Ackerman, I.L. Changes in soil carbon inventories following cultivation of previously untilled soils. Biogeochemistry 1993, 20, 161-193. [CrossRef]

48. Freibauer, A.; Rounsevell, M.D.A.; Smith, P.; Verhagen, J. C sequestration in the agricultural soils of Europe. Geoderma 2004, 122, 1-23. [CrossRef]

49. Smith, P.; Martino, D.; Cai, Z.; Gwary, D.; Janzen, H.; Kumar, P.; McCarl, B.; Ogle, S.; Rice, C.; Scholes, B.; et al. Greenhouse gas mitigation in agriculture. Philos. Trans. R. Soc. B Biol. Sci. 2008, 363, 789-813. [CrossRef] [PubMed]

50. Rhodes, C.J. The 2015 Paris Climate Change Conference: COP21. Sci. Prog. 2016, 99, 97-104. [CrossRef] [PubMed] 
51. Post, M.W. Impact of soil restoration, management and land-use history in forest-soil carbon. In The Potential of U.S. Forest Soils to Sequester Carbon and Mitigate the Greenhouse Effect; CRC Press: New York, NY, USA, 2002; p. 448.

52. Schlesinger, W.H. C sequestration in soils. Science 1999, 284. [CrossRef]

53. Morgan, J.A.; Follett, R.F.; Leon, H.A., Jr.; Del Grosso, S.; Derner, J.D.; Dijkstra, F.; Franzluebbers, A.; Fry, R.; Paustian, K.; Schoeneberger, M.M. Carbon sequestration in agricultural lands of the United States. J. Soil Water Conserv. 2010, 65, 6-13. [CrossRef]

54. Gordon, A.M.; Thevathasan, N.V.; Nair, P.K.R. An agro-ecological foundation for temperate agroforestry. In North American Agroforestry an Integrated Science and Practice; American Society of Agronomy: Madison, WI, USA, 2009; pp. 25-41.

55. Kisambuli, K.E. The Effects of Windbreaks on the Effectiveness of Sprinkler Irrigation Systems; University of Canterbury: Christchurch, New Zealand, 2015; Available online: https:/ ir.canterbury.ac.nz/bitstream/ handle/10092/10420/thesis_fulltextpdf.pdf?sequence=1\&isAllowed=y (accessed on 2 April 2017).

56. Verchot, L.V.; Noordwijk, M.V.; Kandji, S.; Tomich, T.; Ong, C. Climate change: Linking adaptation and mitigation through agroforestry. Mitig. Adapt. Strateg. Glob. Chang. 2007, 12, 901-918. [CrossRef]

57. Torn, M.S.; Harte, J. Missing feedbacks, asymmetric uncertainties, and the underestimation of future warming. Geophy. Res. Lett. 2006, 33, L10703. [CrossRef]

58. Luedeling, E.; Smethurst, P.J.; Baudron, F.; Bayala, J.; Huth, N.I.; van Noordwijk, M.; Ong, C.K.; Mulia, R.; Lusiana, B.; Muthuri, C.; et al. Field-scale modeling of tree-crop interactions: Challenges and development needs. Agric. Syst. 2016, 142, 51-69. [CrossRef]

59. Heisler, G.M. Computer Simulation for Optimizing Windbreak Placement to Save Energy for Heating and Cooling Buildings. Available online: http://www.nrs.fs.fed.us/pubs/jrnl/1991/nrs_1991_heisler_001.pdf (accessed on 14 February 2017).

60. USDA Natural Resource Conservation Service (USDA-NRCS). Conservation Practice Standard: Windbreak/Shelterbelt Establishment (Feet) Code 380. Available online: http:/ /efotg.sc.egov.usda.gov / references/public/MN/380mn.pdf (accessed on 14 February 2017).

61. USDA Natural Resource Conservation Service (USDA-NRCS). Plants Database. Available online: http:/ / www.plants.usda.gov/java/ (accessed on 14 February 2017).

62. Mitsch, W.J.; Wendell, J.W.; Gilliam, P.M.; Groffman, D.L.; Hey, G.W.; Wang, R.; Wang, N. Reducing nitrogen loading to the Gulf of Mexico from the Mississippi river basin: Strategies to counter a persistent ecological problem. Bioscience 2001, 51, 373-388. [CrossRef]

63. Bielinski, M.S. Selecting the right nutrient rate: Basis for managing fertilization programs. HortTechnology 2011, 21, 683-685.

64. Clark, W.; Gellings, K.; Parmenter, E. Energy efficiency in fertilizer production and use. In Efficient Use and Conservation of Energy, Encyclopedia of Life Support Systems (EOLSS); Clark, W.G., Kornelis, B., Eds.; Eolss Publishers: Oxford, UK, 2004; Available online: http://www.eolss.net/sample-chapters/c08/e3-18-04-03. pdf (accessed on 14 February 2017).

65. Martin, D. Estimating the Savings from Improving Pumping Plant Performance, University of Nebraska Extension, 2p. Available online: https:/ / cropwatch.unl.edu/documents/Irrigation\%20Pumping\%20Plant $\%$ 20Savings.pdf (accessed on 14 February 2017).

66. Muratory, M. Rural Energy Use and the Challenges for Energy Conservation and Efficiency. Available online: http:/ / www.nardep.info/uploads/Brief17_RuralEnergyConservation.pdf (accessed on 14 February 2017).

67. Kort, J.; Turnock, R. Carbon reservoir and biomass in Canadian prairie shelterbelts. Agrofor. Syst. 1998, 44, 175-186. [CrossRef]

68. Stoeckeler, J.H. Shelterbelt Influence on Great Plains Field Environment and Crops; Production Research Report No. 62; US Forest Service: Washington, DC, USA, 1962; p. 26.

69. Pelton, W.L. The effect of a windbreak on wind travel, evaporation and wheat yield. Can. J. Plant Sci. 1967, 47, 209-214. [CrossRef]

70. Staple, W.J.; Lehana, J.J. The influence of field shelterbelts on wind velocity, evaporation, soil moisture and crop yield. Can. J. Agric. Sci. 1955, 35, 440-460.

71. George, E.J. Effect of Tree Windbreaks and Slat Barriers on Wind Velocity and Crop Yields; Production Research Report No. 121; USDA: Washington, DC, USA, 1971. 
72. Frank, A.B.; Harris, D.G.; Willis, W.O. Influence of windbreaks on crop performance and snow management in North Dakota. In Shelterbelts on the Great Plains; Tinus, R., Ed.; Great Plane Agriculture Council: Denver, CO, USA, 1975; pp. 41-48.

73. Skidmore, E.L.; Hagen, L.J.; Naylor, D.G.; Teare, J.P. Winter wheat response to barrier induced microclimate. Agron. J. 1974, 66, 501-505. [CrossRef]

74. Nair, P.K.R. Carbon sequestration studies in agroforestry systems: A reality-check. Agrofor. Syst. 2011, 86, 243-253. [CrossRef]

75. Pearce, D.; Koundoury, P. Fertilizer and Pesticide Taxes for Controlling Non-Point Agricultural Pollution, Agriculture and Rural Development, The World Bank Group, 5. Available online: https://pdfs. semanticscholar.org/c604/76541819ed46860a11d0fba3bfd254b75d2b.pdf (accessed on 14 February 2017).

76. Monsanto. Genuity SmartStax RIB Complete Corn. Available online: http://test.monsanto.com/products / pages/genuity-smartstax-rib-complete-corn.aspx (accessed on 14 February 2017).

77. Dow AgroSciences. SmartStax. Available online: http://www.dowagro.com/en-us/usag/product-solutionfinder/traits/smartstax (accessed on 14 February 2017).

(C) 2017 by the authors. Licensee MDPI, Basel, Switzerland. This article is an open access article distributed under the terms and conditions of the Creative Commons Attribution (CC BY) license (http:/ / creativecommons.org/licenses/by/4.0/). 